\title{
Interactions of Dimethyltin(IV) With Uracil as Studied in the Gas Phase
}

\author{
Jean-Yves Salpin* ${ }^{1,2}$, Latifa Latrous ${ }^{3}$, Violette Haldys ${ }^{1,2}$, Al Mokhtar Lamsabhi* ${ }^{4,5}$
}

1. LAMBE, CNRS, Univ Evry, CEA, Université Paris-Saclay, F-91025, Evry, France

2. LAMBE, UCP, Université Paris-Seine, F-91025, Evry,

3. Université de Tunis El Manar, Faculté des Sciences de Tunis, Laboratoire de Chimie Analytique et Electrochimie Campus universitaire 2092, Tunis, Tunisie.

4. Departamento de Química, Módulo 13. Universidad Autónoma de Madrid. Cantoblanco, Campus de Excelencia UAM-CSIC, 28049-Madrid. Spain.

5. Institute of Advanced Chemical Sciences (IadChem). Universidad Autónoma de Madrid, Campus de Excelencia UAM-CSIC, Cantoblanco, 28049-Madrid, Spain

Number of pages (including Tables, Figures, legends and schemes): 35

Corresponding author: Jean-Yves Salpin

Tel: 33169477644 Fax: 33169477655

e-mail : jeanyves.salpin@univ-evry.fr

ORCID

A. M. Lamsabhi : https://orcid.org/0000-0002-1509-2513

J-Y. Salpin: https://orcid.org/0000-0003-0979-1251 


\begin{abstract}
The gas-phase interactions of uracil with dimethyltin(IV) have been studied by a combined experimental and theoretical approach. Positive-ion electrospray spectra show that the interaction of dimethyltin(IV) with uracil (Ura) results in the formation of the $\left[\left(\mathrm{CH}_{3}\right)_{2} \mathrm{Sn}\right.$ (Ura$\mathrm{H})]^{+}$ion. The MS/MS spectrum of this complex is characterized by numerous fragmentation processes, notably associated with elimination of $\mathrm{H}, \mathrm{N}, \mathrm{C}, \mathrm{O}$ and $\mathrm{C}_{3}, \mathrm{H}_{3}, \mathrm{~N}, \mathrm{O}$ moieties, as well as the unusual loss of $\mathrm{C}_{2} \mathrm{H}_{6}$ leading to the $[\mathrm{Sn}(\mathrm{Ura}-\mathrm{H})]^{+}$complex. In turn, the $[\mathrm{Sn}(\mathrm{Ura}-\mathrm{H})]^{+}$ complex fragments according to pathways already observed for the $[\mathrm{Pb}(\mathrm{Ura}-\mathrm{H})]^{+}$analog. Sequential losses of $\mathrm{CH}_{3}$ radicals are also observed from the $\left[\left(\mathrm{CH}_{3}\right)_{2} \mathrm{Sn}(\mathrm{N}, \mathrm{C}, \mathrm{O})\right]^{+}$species $(\mathrm{m} / \mathrm{z}$ 192).

Comparison between DFT-computed vibrational spectra and the IRMPD spectrum recorded between 1000 and $1900 \mathrm{~cm}^{-1}$, shows a good agreement as far as the global minimum is concerned. This comparison points to a bidentate interaction with a deprotonated canonical diketo form of uracil, involving both the N3 and O4 electronegative centers. This binding scheme has been already reported for the $\mathrm{Pb} /$ uracil system. The bidentate form characterized by the interaction between dimethyltin with $\mathrm{N} 3$ and $\mathrm{O} 2$ centers is slightly less stable. Interconversion between the two structures is associated with a small activation barrier (56 $\mathrm{kJ} / \mathrm{mol}$ ). The potential energy surfaces were explored to account for the main fragmentations observed upon collision induced dissociation.
\end{abstract}




\section{Introduction}

Cancer chemotherapy based on metal complexes was initiated by the discovery in the 1960s of cis-diamminedichloroplatinum(II), commonly known as cisplatin (cis-[ $\left.\mathrm{Pt}\left(\mathrm{NH}_{3}\right)_{2} \mathrm{Cl}_{2}\right]$ ). Since, Ptbased antitumor agents have been extensively synthetized and some of these complexes, such as carboplatin, oxaliplatin or iproplatin are used at the clinical level, and have been particularly successful in treating different types of tumors (lung, ovarian, testicular, head, and neck). ${ }^{1,2}$ In spite of the clinical success of the Pt-based agents, side effects, natural and acquired resistance of patients toward the drugs, have motivated the discovery of alternate metal-based antitumor drugs having higher activity and reduced toxicity. Because platinum and tin have common physico-chemical properties such as different oxidation states, organotins (OTCs) have emerged as potential biologically active metallopharmaceuticals. Several hundreds of diorganotin (IV) complexes were synthetized and tested, and the anti-tumor activity and anti proliferative potential of organotins have been regularly reviewed. . $^{3,4,5,6,7,8}$

The antitumor activity of organotins may correspond to different mechanisms occurring at the molecular level. It was shown for example that OTCs may affect the synthesis of macromolecules, by notably inhibiting the synthesis of DNA and proteins. ${ }^{9}$ Other studies pointed to the direct interaction of diorganotins with the phosphate backbone of DNA leading to DNA damage through a change of conformation. ${ }^{10}$ Given the different possible mechanisms of actions, the interaction of the organotin compounds with several biologically relevant species such as amino acids or nucleic acids building blocks have been carried out. ${ }^{11,12,13,14,15,16,17}$ More particularly, NMR studies of aqueous solutions of diethyltin(IV) dichloride with 5'-CMP, 5'dCMP, 5'-UMP, 5'-IMP and 5'-GMP indicated that below $\mathrm{pH} 4$, the diethyltin(IV) moiety is involved in bonding with the phosphate group of the nucleotides. At $\mathrm{pH}>9.5$, the $\mathrm{Et}_{2} \mathrm{Sn}(\mathrm{IV})$ moiety was found to react with the $\mathrm{O}\left(2^{\prime}\right)$ and $\mathrm{O}\left(3^{\prime}\right)$ oxygen atoms of the sugar unit of the nucleotide, whereas at intermediate $\mathrm{pH}$ values (4.0-9.5), there was no evidence for interaction 
with the nucleotide. More recently, an experimental study about the interaction of dimethyltin(IV) with 5'-UMP indicated that the dimethyl tin moiety would not interact with the $\mathrm{N} 3$ atom of the uracil nucleobase, but instead would be involved in a bidentate interaction with the phosphate group. ${ }^{16}$ On the other hand, the formation of $1: 1$ complexes between dipropyltin(IV) and nucleobases through release of a hydrogen atom has been reported, including for uracil (deprotonated at the N3 position, Scheme 1). ${ }^{18}$

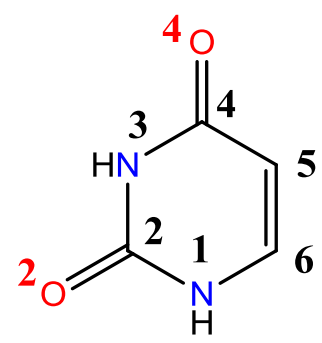

Uracil

Scheme 1: structure of the diketo form of uracil and atom numbering considered during this work

In this context, a better understanding at the molecular level of the interactions between OTCs and DNA building blocks is thought to be helpful. Such information may be accessible through gas-phase studies which get rid of any solvent effect, and the present paper aims at describing the interaction of the smallest diorganotin(IV) compound, namely dimethyltin(IV) with the uracil (Ura) nucleobase. To the best of our knowledge, the interactions taking place between OTCs and nucleobases have not been explored so far by mass spectrometry. Presently, gaseous organotin/uracil complexes were produced by electrospray ionization (ESI), and their unimolecular reactivity has been extensively studied by combining MS/MS experiments, isotope labelling and InfraRed Multiple Photon Dissociation (IRMPD) experiments. In order to rationalize our experimental findings, we also carried out computations using density functional theory. This present paper completes our global study about the interaction of metal ions with nucleobases. 


\section{Methodology}

a) Mass spectrometry.

MS and MS/MS spectra were recorded on a triple-quadrupole instrument (Applied Biosystems/MDS Sciex API 2000), the ions being generated in the gas phase by an electrospray (ESI) source ("turboionspray"). A solution mixture of OTC/uracil $\left(510^{-4} \mathrm{M} / 10^{-4} \mathrm{M}\right.$ in $50 / 50$ methanol/milli-Q water) was infused in the source with a syringe pump. The ESI conditions were as follows: flow rate: $300 \mu \mathrm{l} / \mathrm{h}$; sprayer probe voltage: $5.0 \mathrm{kV}$; pressure of GAS1 (nebulizing gas, air): 2.1 bars; pressure of GAS2 (air): 2.1 bars, temperature of GAS2: $100^{\circ} \mathrm{C}$; pressure of curtain gas $\left(\mathrm{N}_{2}\right): 1.4$ bars.

In order to record low-energy CID spectra, precursor ions were selected by the first mass filter (Q1), then were allowed to collide with nitrogen in the collision cell (Q2), at different collision energies. Finally, the fragment ions were analyzed by the second mass filter (Q3). The collision energy was scanned from 5 to $35 \mathrm{eV}$ (laboratory frame) (the collision energy is set by adjusting the difference of potentials between $\mathrm{Q} 0$ and Q2). The pressure inside the collision cell being of several mTorrs, ${ }^{19}$ MS/MS spectra are very likely obtained under a multiple-collision regime, as discussed previously. ${ }^{20}$

\section{b) IRMPD spectroscopy.}

During the present IRMPD experiments, the fingerprint region $\left(1000-1900 \mathrm{~cm}^{-1}\right)$ has been explored using the beamline of the free electron laser (FEL) of the Centre Laser Infrarouge d'Orsay (CLIO). ${ }^{21}$ The FEL beamline (electron energy set at $44 \mathrm{MeV}$ ) was coupled to a Bruker quadrupole ion trap (Esquire 3000+). This coupling has been described in details in previous reports. $^{22,23,24,25}$ 
The complex of interest has been obtained as gaseous species by ESI of a water/methanol solution prepared as described previously (vide supra). The ESI source parameters were set as follows: flow rate: $180 \mu \mathrm{l} / \mathrm{h}$; spray voltage: $4.5 \mathrm{kV}$; temperature of the transfer capillary: $200{ }^{\circ} \mathrm{C}$. The Bruker Esquire Control (v5.2) software was used to record the IRMPD spectra. To this end, ions of interest were first isolated and then irradiated for $1000 \mathrm{~ms}$ during the MS2 step, the excitation amplitude being concomitantly set to 0 to avoid any CID-like process. Mass spectra were acquired according the following conditions: accumulation time: $20 \mathrm{~ms}$; number of accumulations: 10; $\mathrm{m} / \mathrm{z}$ range: 50-3000; scan resolution: $13000 \mathrm{Th} / \mathrm{s}$. This acquisition cycle was repeated ten times before changing the photon wavelength.

IRMPD spectra are obtained by plotting the photofragmentation yield $\mathrm{R}\left(\mathrm{R}=-\ln \left[\mathrm{I}_{\text {precursor }} /\left(\mathrm{I}_{\text {precursor }}\right.\right.\right.$ $\left.+\Sigma I_{\text {fragments }}\right)$, where $I_{\text {precursor }}$ and $I_{\text {fragments }}$ are the integrated intensities of the mass peaks of the precursor and of the fragment ions, respectively) as a function of the frequency of the IR radiation.

All the $\mathrm{m} / \mathrm{z}$ values discussed in the text correspond to ions incorporating the dominant ${ }^{120} \mathrm{Sn}$ isotope. Uracil and methanol were obtained from Sigma-Aldrich (Saint-Quentin Fallavier, France). Dimethyltin(IV) dichloride $\left(\mathrm{DMTCl}_{2}\right)$ was purchased from Riedel de Haen (Seelze, Germany). All the products were used without further purification.

\section{c) Theoretical study.}

The geometry of the structures of interest were optimized in the gas phase by performing Density functional theory-based approach. To this end, we used the M11-L pure functional ${ }^{26}$ available in the Gaussian 09 suite. ${ }^{27}$ This functional, proposed recently by Truhlar's group has shown reliable results for heavy atoms. ${ }^{26,28,29,30,31,32}$ The Def2-SVP ${ }^{33}$ basis set and effective core potential was used to describe the tin atom, while for the remaining atoms the $6-31+G(d, p)$ basis set was chosen. The choice of this basis set is based on the recent work done by Piotr Matczak who 
showed that the use of this basis set resulted in small errors. ${ }^{34}$ Harmonic vibrational frequencies were computed at the same level in order to estimate the corresponding zero-point vibrational energy (ZPE) corrections and to classify the stationary points of the potential energy surfaces (PES) either as local minima or transition states (TS). Intrinsic reaction coordinate (IRC) calculations were carried out to ascertain the connection between TS and local minima. In order to ensure the reliability of our relative energies when analyzing the topology of the corresponding potential energy surface (PES), the final energy of each of the stationary points was refined by single-point calculations at $\operatorname{CCSD}(\mathrm{T})$ level of theory combined with the same basis set. (see Table S1 of the Supporting Information for additional details).

The bonding characteristics were also investigated by means of the quantum theory of atoms in molecules (QTAIM), ${ }^{35,36}$ in particular through the analysis of the molecular graphs and of the energy density,

$$
h(\vec{r})=v(\vec{r})+g(\vec{r})
$$

where $v(\vec{r})$ and $g(\vec{r})$ are the local densities of the kinetic energies, respectively. The regions in which this magnitude is negative or positive correspond to areas in which the electron density is built up or depleted, respectively, so that the former can be associated with covalent interactions, whereas the latter are typically associated with closed-shell interactions, as in ionic bonds or hydrogen bonds. The molecular graphs are defined by the ensemble of the bond critical points and the bond paths. The corresponding density energy plots have been obtained by means of the AIMALL series of programs. ${ }^{37}$

A complementary viewpoint, sometimes crucial to understand bonding can be obtained through the use of the NBO (Natural Bond Orbital) approach, ${ }^{38}$ which describes the bonding in terms of localized hybrids obtained as local block eigenvectors of the one-particle density matrix. A second order perturbation treatment also allows quantifying the interaction energies between 
occupied and empty orbitals reflected in a charge transfer from the former to the latter. These kinds of interactions are typically found in $\mathrm{XH} \cdots \mathrm{Y}$ hydrogen bonds, which are characterized by a charge transfer from the lone-pairs of the HB acceptor $\mathrm{Y}$, into the antibonding $\sigma_{\mathrm{XH}}{ }^{*}$ orbital of the HB donor, $\mathrm{XH}$.

In order to compute the vibrational spectra of the complexes generated by electrospray, we chose the B3LYP functional instead of M11L. Provided the use of an appropriate scaling factor, the hybrid B3LYP functional has been shown to outperform other DFT methods as well as traditional ab initio approaches to describe both position ${ }^{39}$ and relative intensities ${ }^{40}$ of IR bands. With regard to band positions, a scaling factor of 0.98 was chosen on the basis of the overall good agreement between experimental and computed frequencies for a large set of molecules. Finally, for ease of comparison with the experimental spectrum, calculated spectra were convoluted with a $15 \mathrm{~cm}^{-1}$ Lorentzian function.

\section{Results-discussion}

\section{Positive-ion electrospray spectra of OTC/uracil mixture.}

A series of electrospray mass spectra were acquired by scanning the cone voltage (corresponding to the declustering potential, DP, for our triple-quadrupole instrument) from 0 to $100 \mathrm{~V}$. The spectrum obtained for the uracil/DMTCl 2 mixture at a cone voltage of $15 \mathrm{~V}$ is given in Figure 1a.

\section{$<$ Figure 1 >}

Protonated uracil $(\mathrm{m} / \mathrm{z}, 113)$ is observed in significant abundance but does not dominate the spectrum as it has been observed, for instance, for the $\mathrm{Pb}^{2+} /$ cytosine system. ${ }^{41}$ This is not unexpected because uracil is much less basic than cytosine in the gas phase. ${ }^{42}$

Tin-containing ions can be easily identified because of the specific isotopic distribution of this metal, resulting in characteristic isotopic profiles. Most of the ions detected in the 140-300 mass range include one tin atom. The isotopic profiles also confirm the lack of any chloride atom. 
Interaction between uracil and dimethyltin(IV) dichloride $\left(\mathrm{DMTCl}_{2}\right)$ gives rise to a singly charged complex of general formula $\left[\left(\mathrm{CH}_{3}\right)_{2} \mathrm{Sn}(\mathrm{Ura}-\mathrm{H})\right]^{+}$, detected at $\mathrm{m} / \mathrm{z} 261$ and associated with formal deprotonation of uracil. Working with water/methanol mixtures of solvents slightly increases their relative intensity as compared to the use of pure water. Other tin-containing ions are detected at $m / z \quad 151,167$ and 185 , and correspond very likely to $\left[\left(\mathrm{CH}_{3}\right)_{2} \mathrm{SnH}\right]^{+}$, $\left[\left(\mathrm{CH}_{3}\right)_{2} \mathrm{SnOH}\right]^{+}$and $\left[\left(\mathrm{CH}_{3}\right)_{2} \mathrm{SnOH} .\left(\mathrm{H}_{2} \mathrm{O}\right)\right]^{+}$, respectively. The two latter complexes may result from the hydrolysis of the $\mathrm{DMTCl}_{2}$. Diorganotins indeed have a strong tendency to hydrolysis in aqueous solutions, and it has been shown that they can give rise to aquo, hydroxo or polynuclear complexes of various charge states over a wide $\mathrm{pH}$ range. ${ }^{11,17}$ Note that we do not detect any doubly charged complexes of the type $\left[\left(\mathrm{CH}_{3}\right)_{2} \mathrm{Sn}\left(\mathrm{H}_{2} \mathrm{O}\right)_{n}\right]^{2+}$ known to be formed in water. ${ }^{11,17}$ However, these latter ones may be transiently generated and spontaneously dissociate to generate hydroxo species. Finally, we do not observe any doubly charged complex between tin and uracil, as it was observed for $\mathrm{Pb} .{ }^{43}$ Note that we also tried to examine the reactivity of triorganotins with uracil. However, unlike what we observed with cysteine ${ }^{20}$ or glycine, ${ }^{44}$ we did not detect any complex during these experiments.

\section{Low-energy CID spectra.}

A whole set of MS/MS spectra has been obtained, combining in source fragmentations followed by MS/MS spectra of fragments ions, use of labeled compounds and selection of different tin isotopes. The MS/MS spectrum of the $\left[\left(\mathrm{CH}_{3}\right)_{2} \mathrm{Sn}(\mathrm{Ura}-\mathrm{H})\right]^{+}$complex $(\mathrm{m} / \mathrm{z} 261)$ recorded at a collision energy of $30 \mathrm{eV}$ in the laboratory frame (2.9 eV in the center of mass frame) is shown in Figure 1b. The different experiments performed resulted in the dissociation pattern summarized in Scheme 2 and in Table 1. 
$\left[\left(\mathrm{CH}_{3}\right)_{2} \mathrm{Sn}\left(\mathrm{C}_{3}, \mathrm{H}_{2}, \mathrm{~N}, \mathrm{O}\right)\right]^{+}$

$\mathrm{m} / \mathrm{z} 218$

$\mathrm{m} / \mathrm{z} 218$

$\mathrm{m} / \mathrm{z} 219$

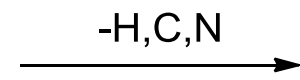

$\left[\left(\mathrm{CH}_{3}\right)_{2} \mathrm{Sn}\left(\mathrm{C}_{2}, \mathrm{H}, \mathrm{O}\right)\right]^{+}$

$\mathrm{m} / \mathrm{z} 191$

$m / z 191$

$\mathrm{m} / \mathrm{z} 191$

$-\mathrm{H}, \mathrm{N}, \mathrm{C}, \mathrm{O}$

$\left[\left(\mathrm{CH}_{3}\right)_{2} \mathrm{Sn}(\mathrm{Ura}-\mathrm{H})\right]^{+}$

$m / z 261$

$\mathrm{m} / \mathrm{z} 262$

$\mathrm{m} / \mathrm{z} 264$

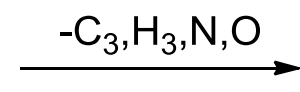

$\left[\left(\mathrm{CH}_{3}\right)_{2} \mathrm{Sn}(\mathrm{N}, \mathrm{C}, \mathrm{O})\right]^{+}$

$m / z 192$
$m / z 193$
$m / z 194$

$$
-\mathrm{C}_{2} \mathrm{H}_{6}
$$

[Sn(Ura-H) $]^{+}$

$m / z 231$

$m / z 232$

$\mathrm{m} / \mathrm{z} 244$

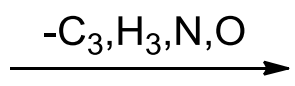

$-\mathrm{C}_{2} \mathrm{H}_{6}$

$[\mathrm{Sn}(\mathbf{N}, \mathbf{C}, \mathbf{O})]^{+}$

$m / z 162$

$m / z 163$

$\mathrm{m} / \mathrm{z} 164$

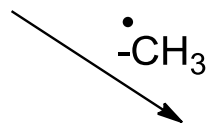

$\left[\left(\mathrm{CH}_{3}\right) \mathrm{Sn}(\mathrm{N}, \mathrm{C}, \mathrm{O})\right]^{+\bullet}$

$\mathrm{m} / \mathrm{z} 177$

$\mathrm{m} / \mathrm{z} 178$

$\mathrm{m} / \mathrm{z} 179$

$-\mathrm{H}, \mathrm{N}, \mathrm{C}, \mathrm{O}$

$\left[\mathrm{Sn}\left(\mathrm{C}_{3}, \mathrm{H}_{2}, \mathbf{N}, \mathbf{O}\right)\right]^{+}$

$\mathrm{m} / \mathrm{z} 188$

$\mathrm{m} / \mathrm{z} 188$

$\mathrm{m} / \mathrm{z} 189$
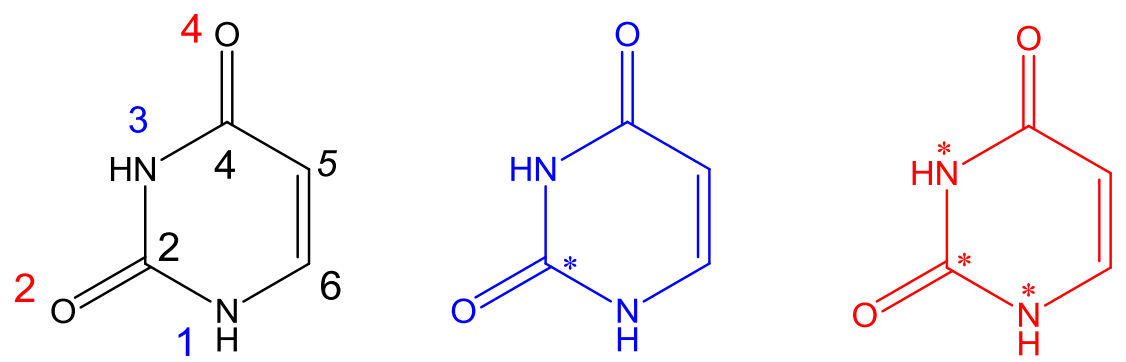

Scheme 2: fragmentation pattern observed when selecting the ${ }^{120} \mathrm{Sn}$ isotope during CID experiments.

Starting from the precursor ion $(\mathrm{m} / z, 261)$, three different processes are observed. The first one, characteristic of this complex, corresponds to the elimination of 30 mass units (very likely associated to the loss of $\left.\mathrm{C}_{2} \mathrm{H}_{6}\right)$ and leads to the $[\mathrm{Sn}(\mathrm{Ura}-\mathrm{H})]^{+}$complex $(\mathrm{m} / z 231)$. The two other processes correspond to the elimination of $43 \mathrm{u}(\mathrm{H}, \mathrm{N}, \mathrm{C}, \mathrm{O})$ and $69 \mathrm{u}\left(\mathrm{C}_{3}, \mathrm{H}_{3}, \mathrm{~N}, \mathrm{O}\right)$, generating the m/z 218 and 192 fragment ions, respectively. These dissociations are also observed for the 
$[\mathrm{Sn}(\mathrm{Ura}-\mathrm{H})]^{+}$ion (giving $\mathrm{m} / \mathrm{z} 188$ and 162 ), and have been already reported for the $[\mathrm{Pb}(\mathrm{Ura}-\mathrm{H})]^{+}$ ion. ${ }^{43}$ Note also that elimination of $43 \mathrm{u}(\mathrm{H}, \mathrm{N}, \mathrm{C}, \mathrm{O})$ is common to both protonated ${ }^{45,46,47,48}$ or metal-uracil. $^{43,49,50,51,52}$ Another interesting dissociation pathway is the sequential elimination of methyl radicals from the $\left[\left(\mathrm{CH}_{3}\right)_{2} \mathrm{Sn}(\mathrm{N}, \mathrm{C}, \mathrm{O})\right]^{+}$complex. Remarkably, such a sequence is not observed from the initial complex. This difference of fragmentation suggests that the NCO moiety may present a radical character within the $\left[\left(\mathrm{CH}_{3}\right)_{2} \mathrm{Sn}(\mathrm{N}, \mathrm{C}, \mathrm{O})\right]^{+}$complex, promoting the homolytic cleavage of the C-Sn bond.

The interactions of uracil with different metal ions have been extensively studied experimentally. In the context of measuring the alkali cation affinity ${ }^{53}$ of uracil, the structure and unimolecular reactivity of $\mathrm{M}^{+}$-uracil complexes $(\mathrm{M}=\mathrm{Li}, \mathrm{Na}, \mathrm{K})$ have been investigated by different techniques. $^{54,55}$ In presence of alkali metals, deprotonation of uracil is not observed and $[\mathrm{M}(\mathrm{Ura})]^{+}$complexes are generated in the gas phase. Upon collision, these complexes react solely by loss of the intact uracil. The reactivity is radically different as far as divalent metals are concerned. Different types of interactions may occur, leading either to singly-charged [M(Ura$\mathrm{H})]^{+}$ions through deprotonation of the nucleobase, ${ }^{43,49,51}$ or doubly-charged $[\mathrm{M}(\mathrm{Ura})]^{2+}$ (M=alkali earth metals) complexes. ${ }^{51}$ In all cases, studies have demonstrated that singly- or doubly-charged complexes of divalent metals dissociate extensively according to numerous fragmentation pathways which involve the cleavage of the pyrimidic ring. Regardless the charge state and the nature of the metal, one process is systematically observed, namely the elimination of $43 \mathrm{u}(\mathrm{H}, \mathrm{N}, \mathrm{C}, \mathrm{O})$. Use of labeled uracils has shown that in presence of $\mathrm{Cu}^{2+}, \mathrm{Pb}^{2+}$ and $\mathrm{Ca}^{2+}$, the loss of HNCO either from the $[\mathrm{M}(\mathrm{Ura}-\mathrm{H})]^{+},{ }^{43,49,51}$ or the $[\mathrm{M}(\mathrm{Ura})]^{2+}$ ion, ${ }^{51}$ involves exclusively the elimination of the $\mathrm{C} 2$ and $\mathrm{N} 3$ atoms and consequently that the $(\mathrm{H}, \mathrm{N} 3, \mathrm{C} 2, \mathrm{O})$ fragment is expelled. According to the present labelling experiments (Table 1), the same process is very likely observed for the $\mathrm{Sn} / \mathrm{uracil}$ complexes. For instance, in presence of $2-{ }^{13} \mathrm{C}$-uracil the $m / z 218$ 
ion is not shifted, demonstrating that the $\mathrm{C} 2$ center is eliminated. Given the similarity between $\mathrm{Sn}$ and $\mathrm{Pb}$ complexes, one may reasonably expect that the N3 center is also eliminated.

\section{Structural characterization of the $\mathrm{Sn} / \mathrm{uracil}$ complexes.}

Computational study. In order to complete our experimental findings, we have carried out DFT calculations in order to characterize in detail the geometry of the $\left[\left(\mathrm{CH}_{3}\right)_{2} \mathrm{Sn}(\mathrm{Ura}-\mathrm{H})\right]^{+}$complex. Starting from different neutral tautomeric forms of uracil, we considered that the deprotonation of uracil to generate the $\left[\left(\mathrm{CH}_{3}\right)_{2} \mathrm{Sn}(\mathrm{Ura}-\mathrm{H})\right]^{+}$complex could formally occur either on N1, N3 or the hydroxyl groups of the various neutral tautomers. Note that the deprotonation of different neutral tautomers can result in the same form. We have tried to optimize both monodentate and bidentate complexes. We have also considered the situation when the $\left(\mathrm{CH}_{3}\right)_{2} \mathrm{Sn}^{2+}$ moiety does not interact with the deprotonated site. The different structures found for the $\left[\left(\mathrm{CH}_{3}\right)_{2} \mathrm{Sn}(\mathrm{Ura}-\mathrm{H})\right]^{+}$ complex complexes are gathered in Figure 2. From this figure, one can see that all the most stable minima are characterized by a metallic center lying in the plane of the nucleobase. Structures with a metal located out of the plane are less stable. The most stable forms always correspond to bicoordinated species. The structures obtained can be classified within two families depending on the structure (diketo or enolic) of uracil. Examination of Figure 2 shows that the enolic forms are systematically less stable than the diketo forms, if one excepts the N1/O2 coordination scheme. Similarly to what was observed for Pb-containing complex, the global minimum, Ura-O4N3, corresponds to a bidentate interaction with the N3 and O4 centers. This particular structure therefore results from the deprotonation of the N3 atom, as it was reported in solution from a potentiometric study. ${ }^{18}$ The interaction of the metal with both N3 and $\mathrm{O} 2$ leads to a slightly less stable form (Ura-O2N3; $+17.2 \mathrm{~kJ} / \mathrm{mol}$ ), whereas the bidentate interaction involving $\mathrm{O} 2$ and the deprotonated $\mathrm{N} 1$ center is significantly less favorable $(+31.7$ $\mathrm{kJ} / \mathrm{mol})$. 


\section{<Figure 2>}

The two most stable forms therefore imply that deprotonation occurs at the N3 position, which is the least acidic nitrogen atom in the gas phase. ${ }^{56,57,58,59}$ Similar N3 deprotonation and N3+O4 interaction has been also evidenced for the $[\mathrm{Pb}(\mathrm{Ura}-\mathrm{H})]^{+}$complex, first theoretically ${ }^{43}$ and more recently experimentally by IRMPD spectroscopy. ${ }^{41,60}$ The same binding scheme has been also systematically characterized for different complexes involving deprotonated uracil, such as $[\mathrm{M}(\mathrm{Ura}-\mathrm{H}) \mathrm{Ura}]^{+} 61,62,63(\mathrm{M}=\mathrm{Mg}, \mathrm{Ca}, \mathrm{Sr}, \mathrm{Ba}, \mathrm{Pb}, \mathrm{Zn}, \mathrm{Cu})$ or $\left[\mathrm{M}(\mathrm{Ura}-\mathrm{H}) \cdot \mathrm{H}_{2} \mathrm{O}_{\mathrm{n}}\right]^{+61,63,64}(\mathrm{M}=\mathrm{Mg}$, $\mathrm{Ca}, \mathrm{Sr}, \mathrm{Ba}, \mathrm{Pb}, \mathrm{Zn} ; \mathrm{n}=1,2)$, by combining action spectroscopy to DFT calculations. One may note the peculiar behavior of the $\mathrm{Cu}^{2+}$ cation within the $\left[\mathrm{Cu}(\mathrm{Ura}-\mathrm{H}) \cdot \mathrm{H}_{2} \mathrm{O}_{n}\right]^{+}$complexes, $(\mathrm{n}=0,1)$ which promotes the deprotonation of $\mathrm{N} 1$ and is involved in a bidentate interaction with $\mathrm{N} 1$ and $\mathrm{O} 2$ electronegative centers. ${ }^{49,52,63}$

When the interaction with the metal does not involve deprotonation of the uracil moiety, a different coordination scheme is generally observed. Both theoretical and/or experimental studies have indeed shown that the $\mathrm{O} 4$ center is the preferred coordination site for $[\mathrm{M}(\mathrm{Ura})]^{+}(\mathrm{M}=$ alkali $\left.\operatorname{metals}^{54,65,66}, \mathrm{Mg}^{+67}\right),\left[\mathrm{M}(\mathrm{Ura}) \cdot \mathrm{H}_{2} \mathrm{O}\right]^{+}$complexes $\left(\mathrm{M}=\right.$ alkali metals $\left.{ }^{68}\right)$ and $[\mathrm{Cu}(\mathrm{Ura})]^{2+}$ ions. $^{69}$ This binding scheme has been experimentally confirmed by IRMPD spectroscopy for the complexes with alkali metal ions. ${ }^{70}$ On the other hand, bidentate interactions with $\mathrm{N} 2$ and $\mathrm{O} 3$ atoms of a tautomeric form of uracil correspond to the most stable structures with alkaline earth metal dications, ${ }^{71,72} \mathrm{Mn}^{2+73}$ and $\mathrm{Cu}^{+} .{ }^{74}$

In order to gain further insights about the structure of the $\left[\left(\mathrm{CH}_{3}\right)_{2} \mathrm{Sn}(\mathrm{Ura}-\mathrm{H})\right]^{+}$complex we have carried out a NBO and AIM population analysis. The main objective is to elucidate the differences that tin presents with respect to other interactions already exposed in the literature. First, we can affirm that the interaction taking place is strong enough that in the NBO analysis the metal presents a bond wherever it is placed. The electron density and the energy density at 
the bond critical points of Sn-N and Sn-O bonds for the most stable complexes (Figure 3) ratify these findings.

\section{$<$ Figure 3>}

If we take the most stable complex as example (Ura-O4N3), the electron density of these bonds is estimated similar for both linkages (about 0.087 a.u) within a negative value of the energy density in each one. So, the bindings present an important covalent character between the metal and the heteroatom involved. Analysis of the Wiberg bond index (WBO) shows the same trends if one focusses on the same linkage. However, compared to what was observed in the cysteineDMT complexes, ${ }^{20}$ the WBO values are slightly higher which might point out to a less pronounced electronic transfer between the interacting entities. In fact, while for cysteine the charge transferred to DMT is around $1.2 \mathrm{e}$, in term of natural charge, the electronic transfer in the case of uracil leads to a net charge on the dimethyltin moiety of about 1.53 e (Table 2).

To get deeper insight on the highest electronic reorganization involved in uracil when the formation of $\left[\left(\mathrm{CH}_{3}\right)_{2} \mathrm{Sn}(\mathrm{Ura}-\mathrm{H})\right]^{+}$complex takes place, we have explored the perturbation at the second order in the NBO population analysis, which allows estimating the interaction energies between occupied and empty orbitals. The electronic donation and retro-donation between the occupied and empty orbitals involved in the interaction has shown higher energy values (Figure 4).

\section{<Figure 4>}

In fact, if we focus on the most stable complex (Ura-O4N3), the donation from the occupied orbital associated to the $\sigma_{\mathrm{N}-\mathrm{Sn}}$ bond to the anti-bonding $\sigma_{\mathrm{C} 2 \mathrm{~N} 1}^{*}$ empty orbital involves about 26.4 $\mathrm{kJ} / \mathrm{mol}$ (Figure 4). Similar energy value is estimated from the donation of $\sigma_{\mathrm{O} 4-\mathrm{Sn}}$ orbital to the empty orbital $\sigma_{\mathrm{C} 4-\mathrm{N} 3}$. About 9.4 and $8.7 \mathrm{~kJ} / \mathrm{mol}$ from occupied orbital $\sigma_{\mathrm{C}-\mathrm{N}}$ to the empty orbitals $\sigma_{\mathrm{N} 3-\mathrm{Sn}}^{*}$ and $\sigma_{\mathrm{O} 4-\mathrm{Sn}}^{*}$, respectively, quantify the back-donation. It is worth noting that in this case 
the orbital of two different $\mathrm{C}-\mathrm{N}$ bonds are involved in the interaction, $\mathrm{C} 2 \mathrm{~N} 1$ and $\mathrm{C} 4 \mathrm{~N} 3$ (Figure 4), which could explain the pronounced stability of this structure over the others. In fact, the linkage strength of DMT to the carbonyl attached at position 4 increases the electronic delocalization in the uracil ring, making the rupture of their bonds more difficult. However, in the structures where the carbonyl group at position 2 is involved, the second order perturbation analysis shows an electronic transfer localized in the region of the interaction. In fact, the donation from $\sigma_{\mathrm{N}-\mathrm{Sn}}$ and $\sigma_{\mathrm{O}-\mathrm{Sn}}$ orbitals falls on the empty orbital $\sigma_{\mathrm{C} 2-\mathrm{N} 1}$ in Ura-O2N3 structure, whereas for the complex Ura-O2N1 the donation from the same occupied orbitals involves the $\sigma_{\text {C2-N3 }}^{*}$ empty orbital. The energies involved in these cases are two times higher than those encountered in the most stable compound.

IRMPD spectrum of the $\left[\left(\mathrm{CH}_{3}\right)_{2} \mathrm{Sn}(\mathrm{Ura}-\mathrm{H})\right]^{+}$complex. According to the theoretical study, the most stable form of the $\left[\left(\mathrm{CH}_{3}\right)_{2} \mathrm{Sn}(\mathrm{Ura}-\mathrm{H})\right]^{+}$ion implies the interaction of both $\mathrm{N} 3$ and $\mathrm{O} 4$ centers with the metal. Consequently, in order to check if this particular structure or alternate forms were actually generated by electrospray, we have recorded its IRMPD spectrum.

Presently, IRMPD spectra have been recorded between 1000 and $1900 \mathrm{~cm}^{-1}$. The fragment ions resulting from the IRMPD activation of the $\left[\left(\mathrm{CH}_{3}\right)_{2} \mathrm{Sn}(\mathrm{Ura}-\mathrm{H})\right]^{+}$complex, are associated with the elimination of $[\mathrm{H}, \mathrm{N}, \mathrm{C}, \mathrm{O}](\mathrm{m} / \mathrm{z}, 218)$ and $\mathrm{C}_{2} \mathrm{H}_{6}(\mathrm{~m} / \mathrm{z}, 231)$, and the experimental spectrum presented in Figure 5a was obtained by taking into account these two photofragments. This spectrum shows a small signal at $1220 \mathrm{~cm}^{-1}$, an intense band at $1475 \mathrm{~cm}^{-1}$ and three very intense features detected at $1565 \mathrm{~cm}^{-1}, 1603$ and $1780 \mathrm{~cm}^{-1}$. The IRMPD bands can be assigned by comparing the experimental spectrum with the DFT-computed vibrational spectra of the most stable optimized structures, and more particularly those involving the diketo form of deprotonated uracil, namely Ura-O4N3, Ura-O2N3 and Ura-O2N1 (Figures 5b-d). It is worth noting that because of the complex nature of the IRMPD process, ${ }^{75,76,77}$ the computed IR 
intensities, which assume single photon absorption, may not correspond well with the experimental abundances.

\section{$<$ Figure 5>}

When examining Figure 5, one can observe that the experimental IRMPD spectrum and the computed IR spectrum of the global minimum Ura-O4N3 (Figure 5b) are in very good agreement. All the IRMPD bands can indeed be assigned by considering the IR active modes of this particular structure, which are summarized in Table 3. The IRMPD feature detected at $1220 \mathrm{~cm}^{-1}$ may be interpreted as the combination of $\mathrm{NH}$ and $\mathrm{CH}$ bending modes. The intense band detected at $1475 \mathrm{~cm}^{-1}$ can be attributed to the $\mathrm{CO}$ stretch of the $\mathrm{C} 4 \mathrm{O} 4$ bond associated with NH bending. The very intense feature detected between 1540 and $1610 \mathrm{~cm}^{-1}$ corresponds to two strong signals. The first one, centred around $1565 \mathrm{~cm}^{-1}$ is associated with $\mathrm{C} 4 \mathrm{C} 5$ and N1C6 bond stretches, whereas the band at $1603 \mathrm{~cm}^{-1}$ can be ascribed to the C5C6 bond stretch. Finally, the very sharp signal detected at $1780 \mathrm{~cm}^{-1}$ correspond to the stretching of the unperturbed $\mathrm{C} 2 \mathrm{O} 2$ carbonyl group. This $\mathrm{C}=\mathrm{O}$ stretching mode is characteristic of the presence of bare keto forms.

Comparison with the vibrational spectrum computed for Ura-O2N3 (Figure 5c) globally shows less agreement, though some vibrations are consistent with some experimental signals. This is the case for the bands observed at 1475 and $1565 \mathrm{~cm}^{-1}$, and consequently this form cannot be completely discarded. On the other hand, the bands experimentally observed at 1603 and 1780 $\mathrm{cm}^{-1}$ are not correctly reproduced since the $\mathrm{C} 5 \mathrm{C} 6$ and $\mathrm{C} 4 \mathrm{O} 4$ carbonyl group stretches are slightly blue-shifted and red-shifted, respectively, with respect to the experimental trace. Finally the Ura-O2N1 structure (Figure 5d) exhibits the worst agreement with experiment. Although it reproduces correctly the experimental CO stretch, the spectrum cannot account for 
the bands measured at 1210, 1475 and 1603 wavenumbers. Consequently, its formation during experiments seems unlikely.

\section{Unimolecular reactivity of the $\left[\left(\mathrm{CH}_{3}\right)_{2} \mathrm{Sn}(\mathrm{Ura}-\mathrm{H})\right]^{+}$complex.}

In order to rationalize the unimolecular reactivity observed upon collision, we have also tried to examine the potential energy surface associated with the formation of the most intense product ions.

As discussed previously (vide supra), the prominent dominant peak in the MS/MS spectrum is detected at $m / z$ 231. The corresponding loss has been assigned to the two methyl moieties which can be also viewed as the elimination of an ethane molecule. According to our computational study, the interaction between deprotonated uracil and the dimethyltin dichloride preserves the integrity of the dimethyltin moiety, the methyl groups being attached to the metal. Hence, all the complexes could be candidate for this fragmentation. Reasonably, the most stable complex is the most probable that may lead to $[\mathrm{Sn}(\mathrm{Ura}-\mathrm{H})]^{+}$by rupture of the $\mathrm{Sn}-\mathrm{C}$ bonds. The activation barrier of the corresponding transition state is estimated at about $225 \mathrm{~kJ} / \mathrm{mol}$ at the $\mathrm{CCSD}(\mathrm{T}) / 6$ $31+\mathrm{G}(\mathrm{d}, \mathrm{p}) / / \mathrm{M} 11 \mathrm{~L} / 6-31+\mathrm{G}(\mathrm{d}, \mathrm{p})$ level of theory (see Figure $6 \mathrm{~b})$. It is worth noting that the resulting fragment ion is similar to the complex obtained in the case of lead interaction with uracil. ${ }^{43}$ Considering that both $[\mathrm{Pb}(\mathrm{Ura}-\mathrm{H})]^{+}$and $[\mathrm{Sn}(\mathrm{Ura}-\mathrm{H})]^{+}$complexes present the same experimental fragmentation patterns, we may reasonable assume that the associates potential energy surfaces would be similar.

\section{<Figure 6>}

Concerning the second more intense peak obtained in the MS/MS spectra, namely $\mathrm{m} / \mathrm{z} 192$, and taking into account the results deduced from isotope labelling, we can propose a mechanism for the formation of $\left[\left(\mathrm{CH}_{3}\right)_{2} \mathrm{SnC}, \mathrm{O}, \mathrm{N}\right]^{+}$from the initial complex. Indeed, this fragment ion undoubtedly contains the $\mathrm{C} 2$ carbon atom (Sscheme 1). As already mentioned in the NBO 
analysis, the interaction of DMT with both $\mathrm{O} 4$ and deprotonated N3 atom of uracil is highly stabilized and results in the strongest $\mathrm{C}-\mathrm{N}$ bonds. Their cleavage, which can lead to desired fragment, turns to be very difficult. All our attempts to find a theoretical transition state by breaking these bonds from the Ura-O4N3 structure were unsuccessful. Alternatively, this process could occur from the second more stable complex, based on the fact that the isomerization toward the Ura-O2N3 structure is associated with a small activation barrier (56 $\mathrm{kJ} / \mathrm{mol}$; Figure 6a). However, the $\mathrm{C} 2-\mathrm{N} 1$ bond is still strong enough that a transfer of $\left(\mathrm{CH}_{3}\right)_{2} \mathrm{Sn}$ entity from $\mathrm{N} 3$ to $\mathrm{N} 1 \mathrm{H}$ was required, leading to a first intermediate, min1, before its cleavage. The activation energy for such transfer was estimated about $247 \mathrm{~kJ} / \mathrm{mol}$ as illustrated in Figure 6c. The second step of the dissociation corresponds to the cleavage of the $\mathrm{C} 2 \mathrm{~N} 1$ and is associated with a small energy barrier $(35 \mathrm{~kJ} / \mathrm{mol})$ with respect to $\mathbf{m i n} \mathbf{1}$, and leads to an intermediate, $\mathbf{m i n} \mathbf{2}$, where the $\left(\mathrm{CH}_{3}\right)_{2} \mathrm{Sn}$ group is part of a macrocycle. The third step corresponds to the formation of the OCN moiety by cleavage of the $\mathrm{N} 3 \mathrm{C} 4$ bond and results in the formation of the min 3 intermediate, in which $\mathrm{Sn}$ interacts with the OCN moiety through $\mathrm{O} 2$, and with a $\mathrm{C}_{2} \mathrm{H}_{3} \mathrm{NO}$ fragment through N1, a tetrahedral arrangement being obtained around the metal. The associated activation energy is about $20 \mathrm{~kJ} \cdot \mathrm{mol}^{-1}$ with respect to min2. The last step is associated with the elimination of the $\mathrm{C}_{2} \mathrm{H}_{3} \mathrm{NO}$ neutral and the formation of the $m / z, 192$ ion.

\section{Conclusion}

The information obtained by complementary experimental and theoretical approaches, allowed the detailed characterization of the $\left[\left(\mathrm{CH}_{3}\right)_{2} \mathrm{Sn}(\mathrm{Ura}-\mathrm{H})\right]^{+}$complex generated in the gas-phase by the interaction between dimethyltin(IV) with uracil. The MS/MS spectra of this complex are characterized by numerous fragmentation processes, notably associated with elimination of $\mathrm{H}, \mathrm{N}, \mathrm{C}, \mathrm{O}$ and $\mathrm{C}_{3}, \mathrm{H}_{3}, \mathrm{~N}, \mathrm{O}$ moieties, and a characteristic loss of $\mathrm{C}_{2} \mathrm{H}_{6}$ leading to the $[\mathrm{Sn}(\mathrm{Ura}-\mathrm{H})]^{+}$ 
complex. Sequential losses of $\mathrm{CH}_{3}$ radicals are also observed from the $\left[\left(\mathrm{CH}_{3}\right)_{2} \mathrm{Sn}(\mathrm{N}, \mathrm{C}, \mathrm{O})\right]^{+}$ species.

Comparison between DFT-computed IR spectra and IRMPD data indicates that the $\left(\mathrm{CH}_{3}\right)_{2} \mathrm{Sn}^{2+}$ moiety establishes a bidentate interaction with the deprotonated uracil, involving the N3 and O4 centers of the uracil diketo form, deprotonation occurring at N3 like in solution. An O2N3 form cannot be rigorously excluded although the agreement with experiment is not as good as with the O4N3 structure.

The DFT study also points out a strong interaction between the nucleobase and the metal. The NBO analysis ratify these findings by showing up the existence of a bond between the metal and the heteoroatoms involved and the higher energy of the electronic donation and the backdonation between the $\sigma$ orbital of the formed bonds and the $\pi$ orbital of the nucleobase C-N bonds. Several dissociation pathways are explored to rationalize the formation of the main fragment ions generated by collision induced dissociation.

\section{Acknowledgements}

The CLIO team (J. M. Ortega, C. Six, G. Perilhous, J. P. Berthet) as well as P. Maître and V. Steinmetz are warmly acknowledged for their support during the FEL experiments.

This work has been partially supported by the DGI Projects no. CTQ2015-63997-C2, by the Project MADRISOLAR2, Ref.: S2009PPQ/1533 of the Comunidad de Madrid, and by Consolider on Molecular Nanoscience CSC2007-00010. A generous allocation of computing time at the Centro de Computación Científica of the UAM is also acknowledged.

\section{Supporting Information}

Detailed computational information is given into a supporting information. This material is available via the Internet at http://pubs.acs.org/ 


\section{Bibliography}

1. Platinum and Other Metal Coordination Compounds in Cancer Chemotherapy. In Platinum and Other Metal Coordination Compounds in Cancer Chemotherapy, Howell, S. B., Ed. Plenum Press: New-York, 1996.

2. Boulikas, T.; Pantos, A.; Bellis, E.; Christofis, P., designing platinum compounds in cancer structures and mechanisms. Cancer Therapy 2007, 5, 537-583.

3. Gielen, M., Tin-based antitumour drugs. Coord. Chem. Rev. 1996, 151, 41-51.

4. Clarke, M. J.; Zhu, F. C.; Frasca, D. R., Non-platinum chemotherapeutic metallopharmaceuticals. Chem. Rev. 1999, 99 (9), 2511-2533.

5. Gielen, M.; Biesemans, M.; Willem, R., Organotin compounds: from kinetics to stereochemistry and antitumour activities. Appl. Organomet. Chem. 2005, 19 (4), 440-450.

6. Pellei, M.; Lobbia, G. G.; Mancini, M.; Spagna, R.; Santini, C., Synthesis and characterization of new organotin(IV) complexes with polyfunctional ligands. J. Organomet. Chem. 2006, 691 (8), 1615-1621.

7. Hadjikakou, S. K.; Hadjiliadis, N., Antiproliferative and anti-tumor activity of organotin compounds. Coord. Chem. Rev. 2009, 253 (1-2), 235-249.

8. Amir, M. K.; Khan, S.; Zia ur, R.; Shah, A.; Butler, I. S., Anticancer activity of organotin(IV) carboxylates. Inorg. Chim. Acta 2014, 423, 14-25.

9. Marinovich, M.; Viviani, B.; Galli, C. L., Reversibility of tributyltin-chloride-induced protein synthesis inhibition after ATP recovery in HEL-30 cells. Toxicol. Lett. 1990, 52 (3), 311-317.

10. Kuo, L. Y.; Kanatzidis, M. G.; Sabat, M.; Tipton, A. L.; Marks, T. J., Metallocene antitumor agents. Solution and solid-state molybdenocene coordination chemistry of DNA constituents. J. Am. Chem. Soc. 1991, 113 (24), 9027-9045.

11. Pellerito, L.; Nagy, L., Organotin(IV)(n+) complexes formed with biologically active ligands: equilibrium and structural studies, and some biological aspects. Coord. Chem. Rev. 2002, 224 (1-2), 111-150.

12. Atkinson, A.; Rodriguez, M. D.; Shewmaker, T. E.; Walmsley, J. A., Synthesis and characterization of compounds of di- and tributyltin chloride with adenine and guanine mononucleotides. Inorg. Chim. Acta 1999, 285 (1), 60-69.

13. Barone, G.; Barbieri, R.; La Manna, G.; Koch, M. H. J., The interaction of deoxyribonucleic acid with methyltin(IV) moieties in solution studied by small-angle X-ray scattering, circular dichroism and UV spectroscopy. Appl. Organomet. Chem. 2000, 14 (4), 189-196.

14. Yang, Z.; Bakas, T.; Sanchez-Diaz, A.; Charalampopoulos, C.; Tsangaris, J.; Hadjiliadis, N., Interaction of Et2SnCl2 with 5'-IMP and 5'-GMP. J. Inorg. Biochem. 1998, 72 (3), 133-140. 
15. Ghys, L.; Biesemans, M.; Gielen, M.; Garoufis, A.; Hadjiliadis, N.; Willem, R.; Martins, José C., Multinuclear 1D and 2D NMR Investigations on the Interaction between the Pyrimidic Nucleotides 5'- CMP, 5'- dCMP, and 5'- UMP and Diethyltin Dichloride in Aqueous Medium. Eur. J. Inorg. Chem. 2000, 2000 (3), 513-522.

16. Gharib, F.; Jaberi, F.; Zandevakili, M., Interaction of dimethyltin(IV) dichloride with 5'-IMP and 5'-UMP. Appl. Organomet. Chem. 2008, 22 (4), 215-220.

17. Nath, M.; Pokharia, S.; Yadav, R., Organotin(IV) complexes of amino acids and peptides. Coord. Chem. Rev. 2001, 215, 99-149.

18. Al-Najjar, A. A.; Mohamed, M. M. A.; Shoukry, M. M., Interaction of dipropyltin(IV) with amino acids, peptides, dicarboxylic acids and DNA constituents. J. Coord. Chem. 2006, 59 (2), 193-206.

19. Chernushevich, I. V.; Loboda, A. V.; Thomson, B. A., An introduction to quadrupoletime-of-flight mass spectrometry. J. Mass Spectrom. 2001, 36 (8), 849-865.

20. Latrous, L.; Salpin, J. Y.; Haldys, V.; Léon, E.; Correia, C.; Lamsabhi, A., Gas-phase interactions of organotin compounds with cysteine. J. Mass Spectrom. 2016, 51, 1006-1015.

21. Prazeres, R.; Glotin, F.; Insa, C.; Jaroszynski, D. A.; Ortega, J. M., Two-colour operation of a Free-Electron Laser and applications in the mid-infrared. Eur. Phys. J. D 1998, $3(1), 87-93$.

22. MacAleese, L.; Simon, A.; McMahon, T. B.; Ortega, J. M.; Scuderi, D.; Lemaire, J.; Maitre, P., Mid-IR spectroscopy of protonated leucine methyl ester performed with an FTICR or a Paul type ion-trap. Int. J. Mass Spectrom. 2006, 249, 14-20.

23. Chiavarino, B.; Crestoni, M. E.; Fornarini, S.; Lemaire, J.; Maitre, P.; MacAleese, L., pi-complex structure of gaseous benzene-NO cations assayed by IR multiple photon dissociation spectroscopy. J. Am. Chem. Soc. 2006, 128 (38), 12553-12561.

24. Feyer, V.; Plekan, O.; Richter, R.; Coreno, M.; de Simone, M.; Prince, K. C.; Trofimov, A. B.; Zaytseva, I. L.; Schirmer, J., Tautomerism in Cytosine and Uracil: A Theoretical and Experimental X-ray Absorption and Resonant Auger Study. J. Phys. Chem. A 2010, 114 (37), 10270-10276.

25. Simon, A.; MacAleese, L.; Maitre, P.; Lemaire, J.; McMahon, T. B., Fingerprint Vibrational Spectra of Protonated Methyl Esters of Amino Acids in the Gas Phase. J. Am. Chem. Soc. 2007, 129 (10), 2829.

26. Peverati, R.; Truhlar, D. G., M11-L: A Local Density Functional That Provides Improved Accuracy for Electronic Structure Calculations in Chemistry and Physics. J. Phys. Chem. Lett. 2012, 3 (1), 117-124.

27. Frisch, M. J.; Trucks, G. W.; Schlegel, H. B.; Scuseria, G. E.; Robb, M. A.; Cheeseman, J. R.; Scalmani, G.; Barone, V.; Mennucci, B.; Petersson, G. A. et al. Gaussian09, Revision C.01; Gaussian, Inc.: Wallingford CT, 2009. 
28. Li, R.; Peverati, R.; Isegawa, M.; Truhlar, D. G., Assessment and Validation of Density Functional Approximations for Iron Carbide and Iron Carbide Cation. J. Phys. Chem. A 2013, 117 (1), 169-173.

29. Mardirossian, N.; Head-Gordon, M., Characterizing and Understanding the Remarkably Slow Basis Set Convergence of Several Minnesota Density Functionals for Intermolecular Interaction Energies. J. Chem.Theory Comput. 2013, 9 (10), 4453-4461.

30. Liu, H.; Bara, J. E.; Turner, C. H., Tuning the Adsorption Interactions of Imidazole Derivatives with Specific Metal Cations. J. Phys. Chem. A 2014, 118 (22), 3944-3951.

31. Liu, S.; Shen, H.; Yu, Z.; Shi, L.; Yang, Z.; Lan, Y., What Controls Stereoselectivity and Reactivity in the Synthesis of a trans-Decalin with a Quaternary Chiral Center via the Intramolecular Pauson-Khand Reaction: A Theoretical Study. Organometallics 2014, 33 (22), 6282-6285.

32. Schwabe, T., An isomeric reaction benchmark set to test if the performance of stateof-the-art density functionals can be regarded as independent of the external potential. Phys. Chem. Chem. Phys. 2014, 16 (28), 14559-14567.

33. Metz, B.; Stoll, H.; Dolg, M., Small-core multiconfiguration-Dirac-Hartree-Fockadjusted pseudopotentials for post-d main group elements: Application to $\mathrm{PbH}$ and $\mathrm{PbO} . J$. Chem. Phys. 2000, 113 (7), 2563-2569.

34. Matczak, P., Assessment of various density functionals for intermolecular $\mathrm{N} \rightarrow \mathrm{Sn}$ interactions: The test case of poly(trimethyltin cyanide). Comput. Theor. Chem. 2015, 1051, 110-122.

35. Bader, R. F. W., Atoms In Molecules : A Quantum Theory. Clarendon Press Oxford Univ.: Oxford, 1990.

36. Matta, C. F.; Boyd, R. J., The Quantum Theory of Atoms in Molecules. Wiley-VCH Verlag GmbH \& Co.: KGaA: Wein- heim, 2007.

37. Keith, T. A. AIMAll, 15.05.18; 2015.

38. Weinhold, F.; R. Landis, C., Valency and Bonding: A Natural Bond Orbital DonorAcceptor Perspective. Cambridge University Press: Cambridge, 2005.

39. Halls, M. D.; Velkovski, J.; Schlegel, H. B., Harmonic frequency scaling factors for Hartree-Fock, S-VWN, B-LYP, B3-LYP, B3-PW91 and MP2 with the Sadlej pVTZ electric property basis set. Theor. Chem. Acc. 2001, 105 (6), 413-421.

40. Halls, M. D.; Schlegel, H. B., Comparison of the performance of local, gradientcorrected, and hybrid density functional models in predicting infrared intensities. J. Chem. Phys. 1998, 109 (24), 10587-10593.

41. Salpin, J. Y.; Haldys, V.; Guillaumont, S.; Tortajada, J.; Hurtado, M.; Lamsabhi, A., Gas-Phase Interactions between Lead(II) Ions and Cytosine: Tandem Mass Spectrometry and Infrared Multiple-Photon Dissociation Spectroscopy Study. ChemPhysChem 2014, 15 (14), 2959-2971. 
42. Lias, S. G.; Bartmess, J. E.; Liebman, J. F.; Holmes, J. L.; Levin, R. D.; Mallard, W. G., Ion Energetics Data. National Institute of Standards and Technology: Gaithersburg.

43. Guillaumont, S.; Tortajada, J.; Salpin, J. Y.; Lamsabhi, A. M., Experimental and computational study of the gas-phase interactions between lead(II) ions and two pyrimidic nucleobases: Uracil and thymine. Int. J. Mass Spectrom. 2005, 243 (3), 279-293.

44. Latrous, L.; Tortajada, J.; Haldys, V.; Leon, E.; Correia, C.; Salpin, J. Y., Gas-phase interactions of organotin compounds with glycine. J. Mass Spectrom. 2013, 48 (7), 795-806.

45. Nelson, C. C.; McCloskey, J. A., Collision-Induced Dissociation of Uracil and Its Derivatives. J. Am. Soc. Mass Spectrom. 1994, 5 (5), 339-349.

46. Qian, M.; Yang, S.; Wu, H.; Majumdar, P.; Leigh, N.; Glaser, R., Ammonia elimination from protonated nucleobases and related synthetic substrates. J. Am. Soc. Mass Spectrom. 2007, 18 (11), 2040-2057.

47. Yao, C. X.; Cuadrado-Peinado, M. L.; Polasek, M.; Turecek, F., Gas-phase tautomers of protonated 1-methylcytosine. Preparation, energetics, and dissociation mechanisms. $J$. Mass Spectrom. 2005, 40 (11), 1417-1428.

48. Yao, C.; Tureček, F.; Polce, M. J.; Wesdemiotis, C., Proton and hydrogen atom adducts to cytosine. An experimental and computational study. Int. J. Mass Spectrom. 2007, 265, 106-123.

49. Lamsabhi, A. M.; Alcamí, M.; Mó, O.; Yáñez, M.; Tortajada, J.; Salpin, J. Y., Unimolecular Reactivity of Uracil-Cu ${ }^{2+}$ Complexes in the Gas Phase. ChemPhysChem 2007, $8(1), 181-187$.

50. Salpin, J. Y.; Guillaumont, S.; Tortajada, J.; Lamsabhi, A. M., Gas-Phase Interactions Between Lead(II) Ions and Thiouracil Nucleobases: A Combined Experimental and Theoretical Study. J. Am. Soc. Mass Spectrom. 2009, 20 (3), 359-369.

51. Trujillo, C.; Lamsabhi, A.; Mo, O.; Yanez, M.; Salpin, J. Y., Unimolecular reactivity upon collision of uracil- $\mathrm{Ca}(2+)$ complexes in the gas phase: Comparison with uracil-M(+) $(\mathrm{M}$ $=\mathrm{H}$, alkali metals $)$ and uracil- $\mathrm{M}(2+)(\mathrm{M}=\mathrm{Cu}, \mathrm{Pb})$ systems. Int. J. Mass Spectrom. 2011, 306 (1), 27-36.

52. Ali, O. Y.; Fridgen, T. D., Structures and Fragmentation of $\mathrm{Cu}($ Uracil-H)(Uracil) plus in the Gas Phase. ChemPhysChem 2012, 13 (2), 588-596.

53. Rodgers, M. T.; Armentrout, P. B., Cationic Noncovalent Interactions: Energetics and Periodic Trends. Chem. Rev. 2016, 116 (9), 5642-5687.

54. Cerda, B. A.; Wesdemiotis, $\mathrm{C}$., $\mathrm{Li}+, \mathrm{Na}+$, and $\mathrm{K}+$ binding to the DNA and RNA nucleobases. Bond energies and attachment sites from the dissociation of metal ion-bound heterodimers. J. Am. Chem. Soc. 1996, 118 (47), 11884-11892.

55. Rodgers, M. T.; Armentrout, P. B., Noncovalent interactions of nucleic acid bases (uracil, thymine, and adenine) with alkali metal ions. Threshold collision-induced dissociation and theoretical studies. J. Am. Chem. Soc. 2000, 122 (35), 8548-8558. 
56. Chandra, A. K.; Nguyen, M. T.; Uchimaru, T.; Zeegers-Huyskens, T., Protonation and deprotonation enthalpies of guanine and adenine and implications for the structure and energy of their complexes with water: Comparison with uracil, thymine, and cytosine. J. Phys. Chem. A 1999, 103 (44), 8853-8860.

57. Kurinovich, M. A.; Lee, J. K., The acidity of uracil from the gas phase to solution: The coalescence of the $\mathrm{N} 1$ and $\mathrm{N} 3$ sites and implications for biological glycosylation. J. Am. Chem. Soc. 2000, 122 (26), 6258-6262.

58. Huang, Y. Q.; Kenttamaa, H., Theoretical estimations of the $298 \mathrm{~K}$ gas-phase acidities of the pyrimidine-based nucleobases uracil, thymine, and cytosine. J. Phys. Chem. A 2003, 107 (24), 4893-4897.

59. Miller, T. M.; Arnold, S. T.; Viggiano, A. A.; Miller, A. E. S., Acidity of a nucleotide base: Uracil. J. Phys. Chem. A 2004, 108 (16), 3439-3446.

60. Ali, O. Y.; Fridgen, T. D., Structures of electrosprayed $\mathrm{Pb}($ Uracil-H)(+) complexes by infrared multiple photon dissociation spectroscopy. Int. J. Mass Spectrom. 2011, 308 (2-3), $167-174$.

61. Power, A. A.; Ali, O. Y.; Burt, M. B.; Fridgen, T. D., IRMPD spectroscopic and computational study of gas phase $\mathrm{IM}(\mathrm{Ura}-\mathrm{H})(\mathrm{Ura})(+)$ and $\mathrm{M}(\mathrm{Ura}-\mathrm{H})(\mathrm{H} 2 \mathrm{O})(\mathrm{n})(+)(\mathrm{M}=\mathrm{Sr}$, $\mathrm{Ba} ; \mathrm{n}=1,2)$ complexes. Int. J. Mass Spectrom. 2012, 330, 233-240.

62. Power, B.; Haldys, V.; Salpin, J. Y.; Fridgen, T. D., Structures of bare and singly hydrated $\mathrm{M}(\mathrm{Ura}-\mathrm{H})(\mathrm{Ura})(+)(\mathrm{M}=\mathrm{Mg}, \mathrm{Ca}, \mathrm{Sr}, \mathrm{Ba})$ complexes in the gas phase by IRMPD spectroscopy in the fingerprint region. Int. J. Mass Spectrom. 2015, 378, 328-335.

63. Power, B.; Haldys, V.; Salpin, J.-Y.; Fridgen, T. D., Structures of $[\mathrm{M}(\mathrm{Ura}-\mathrm{H})(\mathrm{Ura})]+$ and $[\mathrm{M}(\mathrm{Ura}-\mathrm{H})(\mathrm{H} 2 \mathrm{O}) \mathrm{n}]+(\mathrm{M}=\mathrm{Cu}, \mathrm{Zn}, \mathrm{Pb} ; \mathrm{n}=1-3)$ complexes in the gas phase by IRMPD spectroscopy in the fingerprint region and theoretical studies. Int. J. Mass Spectrom. 2017, available on-line.

64. Power, B.; Haldys, V.; Salpin, J. Y.; Fridgen, T. D., Structures of M(Ura-H)(H2O)(n) (+) $(\mathrm{M}=\mathrm{Mg}, \mathrm{Ca}, \mathrm{Sr}, \mathrm{Ba} ; \mathrm{n}=1-3)$ complexes in the gas phase by IRMPD spectroscopy and theoretical studies. J. Mass Spectrom. 2016, 51 (3), 236-244.

65. Armentrout, P. B.; Rodgers, M. T., An absolute sodium cation affinity scale: Threshold collision-induced dissociation experiments and ab initio theory. J. Phys. Chem. A 2000, 104 (11), 2238-2247.

66. Russo, N.; Toscano, M.; Grand, A., Lithium affinity for DNA and RNA nucleobases. The role of theoretical information in the elucidation of the mass spectrometry data. J. Phys. Chem. B 2001, 105 (20), 4735-4741.

67. Liu, H. C.; Sun, J. L.; Hu, Y. H.; Han, K. L.; Yang, S. H., Photodissociation of gaseous metal ion-nucleobase complexes: $\mathrm{Mg}+-$ uracil and $\mathrm{Mg}+$-thymine. Chem. Phys. Lett. 2004, 389 (4-6), 342-347.

68. Gillis, E. A. L.; Rajabi, K.; Fridgen, T. D., Structures of Hydrated Li+-Thymine and Li+-Uracil Complexes by IRMPD Spectroscopy in the N-H/O-H Stretching Region. J. Phys. Chem. A 2009, 113 (5), 824-832. 
69. Marino, T.; Toscano, M.; Russo, N.; Grand, A., Gas-phase interaction between DNA and RNA bases and copper(II) ion: A density functional study. Int. J. Quantum Chem. 2004, 98 (4), 347-354.

70. Nei, Y. W.; Akinyemi, T. E.; Kaczan, C. M.; Steill, J. D.; Berden, G.; Oomens, J.; Rodgers, M. T., Infrared multiple photon dissociation action spectroscopy of sodiated uracil and thiouracils: Effects of thioketo-substitution on gas-phase conformation. Int. J. Mass Spectrom. 2011, 308 (2-3), 191-202.

71. Russo, N.; Toscano, M.; Grand, A., Gas-phase absolute $\mathrm{Ca} 2+$ and $\mathrm{Mg} 2+$ affinity for nucleic acid bases. A theoretical determination. J. Phys. Chem. A 2003, 107 (51), 11533 11538 .

72. Trujillo, C.; Lamsabhi, A. M.; Mó, O.; Yáñez, M.; Salpin, J. Y., Interaction of $\mathrm{Ca}^{2+}$ with uracil and its thio derivatives in the gas phase. Org. Biomol. Chem. 2008, 6 (20), 36953702 .

73. Russo, N.; Sicilia, E.; Toscano, M.; Grand, A., On the interaction between manganese cation $(\mathrm{Mn} 2+)$ and the nucleic acid bases $(\mathrm{T}, \mathrm{U}, \mathrm{C}, \mathrm{A}, \mathrm{G})$ in the gas phase. Int. J. Quantum Chem. 2002, 90 (2), 903-909.

74. Lamsabhi, A. M.; Alcamí, M.; Mó, O.; Yáñez, M., Gas-phase reactivity of uracil, 2thiouracil, 4-thiouracil, and 2,4-dithiouracil towards the $\mathrm{Cu}^{+}$cation: A DFT study. ChemPhysChem 2003, 4 (9), 1011-1016.

75. Lemaire, J.; Boissel, P.; Heninger, M.; Mauclaire, G.; Bellec, G.; Mestdagh, H.; Simon, A.; Le Caer, S.; Ortega, J. M.; Glotin, F.; Maitre, P., Gas Phase Infrared Spectroscopy of Selectively Prepared Ions. Phys. Rev. Lett. 2002, 89, 273002-1.

76. Oomens, J.; Sartakov, B. G.; Meijer, G.; von Helden, G., Gas-phase infrared multiple photon dissociation spectroscopy of mass-selected molecular ions. Int. J. Mass Spectrom. 2006, 254 (1-2), 1-19.

77. Correia, C. F.; Balaj, P. O.; Scuderi, D.; Maitre, P.; Ohanessian, G., Vibrational signatures of protonated, phosphorylated amino acids in the gas phase. J. Am. Chem. Soc. 2008, 130 (11), 3359-3370. 


\section{Table and Figure Caption}

Figure 1: a) Positive-ion electrospray mass spectrum of an 5:1 mixture of $\left(\mathrm{CH}_{3}\right)_{2} \mathrm{SnCl}_{2}$ /uracil $\left(\mathrm{H}_{2} \mathrm{O} /\right.$ methanol $\left.50 / 50 \mathrm{v} / \mathrm{v}\right)$ recorded at $\mathrm{DP}=15 \mathrm{~V}$, and b) low-energy CID spectrum of $\left[\left(\mathrm{CH}_{3}\right)_{2} \mathrm{Sn}(\mathrm{Ura}-\mathrm{H})\right]^{+}$ions recorded with a collision energy of $30 \mathrm{eV}$ (laboratory frame).

Figure 2: Structure and $\operatorname{CCSD}(\mathrm{T}) / 6-31+\mathrm{G}(\mathrm{d}, \mathrm{p}) / / \mathrm{M} 11 \mathrm{~L} / 6-31+\mathrm{G}(\mathrm{d}, \mathrm{p}) .+\mathrm{ZPE}$ relative energies $(\mathrm{kJ} / \mathrm{mol})$ of the lowest-energy structures obtained for the $\left[\left(\mathrm{CH}_{3}\right)_{2} \mathrm{Sn}(\mathrm{Ura}-\mathrm{H})\right]^{+}$complex. Values obtained at the M11L/6-31+G(d,p)+ZPE level are given in parenthesis.

Figure 3: AIM topological analysis of the structures involving the diketo forms of uracil.

Figure 4: NBO molecular orbital interactions between occupied and empty orbitals in the most important complexes (values are $\mathrm{kJ} / \mathrm{mol}$ ).

Figure 5: (a) IRMPD spectrum obtained for the $\left[\left(\mathrm{CH}_{3}\right)_{2} \mathrm{Sn}(\mathrm{Ura}-\mathrm{H})\right]^{+}$complex compared to DFT-computed IR absorption spectra $(\mathbf{b}-\mathbf{d})$ of some relevant structures. The experimental IRMPD spectrum is overlayed in grey.

Figure 6: Energy profile associated with the a) Ura-O4N3 $\rightarrow$ Ura-O2N3 interconversion, b) the formation of $\mathrm{C}_{2} \mathrm{H}_{6}$ and $[\mathrm{Sn}(\mathrm{Ura}-\mathrm{H})]^{+}$fragments $(\mathrm{m} / \mathrm{z}, 231)$, and c) the formation of $\left(\mathrm{C}_{3}, \mathrm{H}_{3}, \mathrm{O}, \mathrm{N}\right)$ and $\left[\left(\mathrm{CH}_{3}\right)_{2} \mathrm{SnNCO}\right]^{+}$fragments $\left(\mathrm{m} / \mathrm{z}\right.$ 192) from the $\left[\left(\mathrm{CH}_{3}\right)_{2} \mathrm{Sn}(\mathrm{Ura}-\mathrm{H})\right]^{+}$ precursor ion. Relative energies are given in $\mathrm{kJ} / \mathrm{mol}$ at the $\operatorname{CCSD}(\mathrm{T}) / 6-31+\mathrm{G} * * / / \mathrm{M} 11 \mathrm{~L} / 6$ $31+\mathrm{G}^{* *}$ level of theory.

Table 1: product ions observed in the fragmentation of different labeled uracil $\left[\left(\mathrm{CH}_{3}\right)_{2} \mathrm{Sn}(\mathrm{Ura}-\mathrm{H})\right]^{+}$complexes. $\mathrm{m} / \mathrm{z}$ values are given for the ions including the ${ }^{120} \mathrm{Sn}$ isotope.

Table 2: Natural charge (in e) on the metal and DMT moiety in the complex, and Wiberg bond index of the most relevant bonds in the complexes.

Table 3: Experimental and computed IR vibrational bands for the $\left[\left(\mathrm{CH}_{3}\right)_{2} \mathrm{Sn}(\mathrm{Ura}-\mathrm{H})\right]^{+}$ complex. 

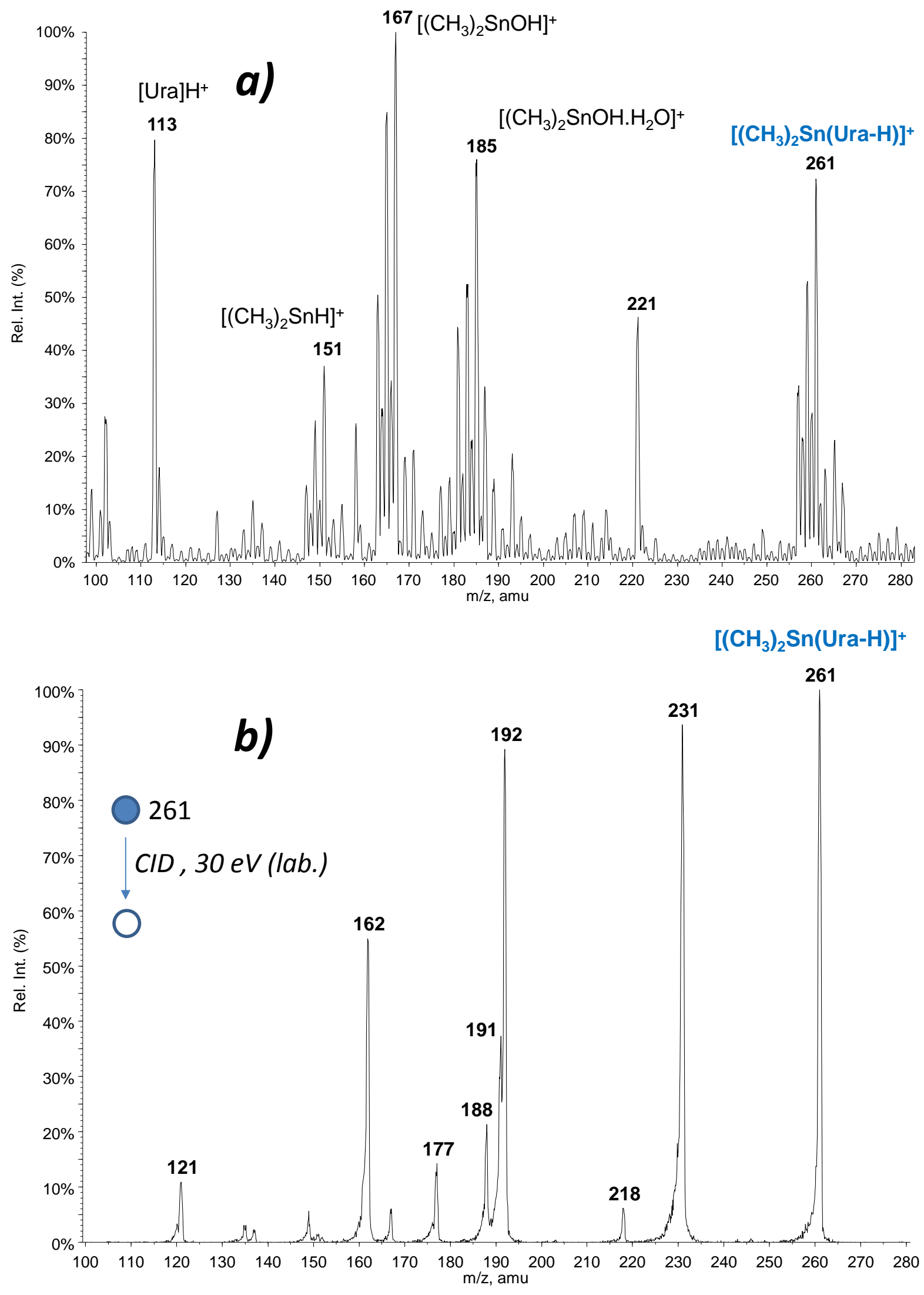

Figure 1: a) Positive-ion electrospray mass spectrum of an 5:1 mixture of $\left(\mathrm{CH}_{3}\right)_{2} \mathrm{SnCl}_{2} / \mathrm{uracil}$ $\left(\mathrm{H}_{2} \mathrm{O} /\right.$ methanol $\left.50 / 50 \mathrm{v} / \mathrm{v}\right)$ recorded at $\mathrm{DP}=15 \mathrm{~V}$, and b) low-energy $\mathrm{CID}$ spectrum of $\left[\left(\mathrm{CH}_{3}\right)_{2} \mathrm{Sn}(\mathrm{Ura}-\mathrm{H})\right]^{+}$ions recorded with a collision energy of $30 \mathrm{eV}$ (laboratory frame). 


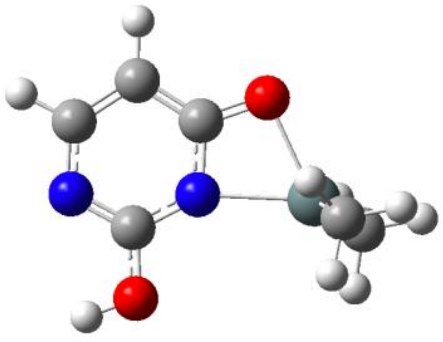

Ura-O4N3-O2H-2

29.3 (20.9)

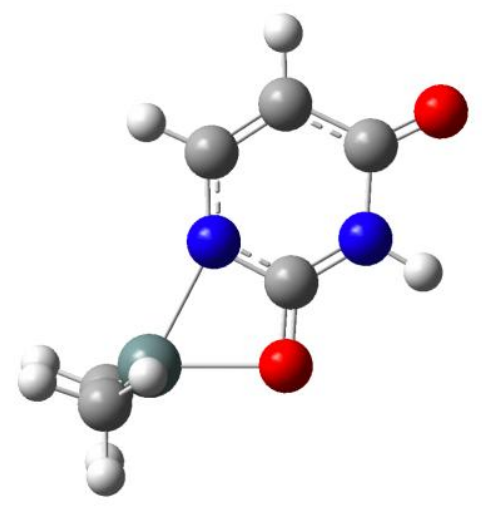

Ura-O2N1

31.7 (37.1)

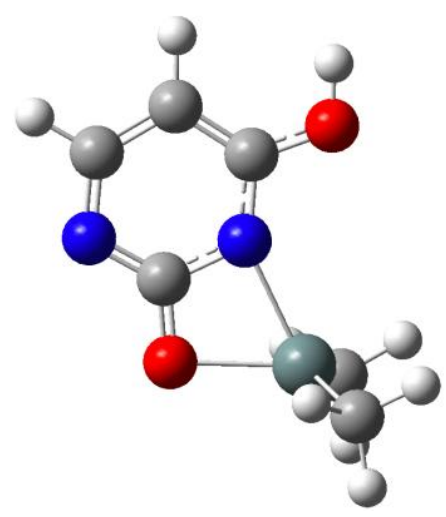

Ura-O2N3-O4H-2

52.0 (41.7)

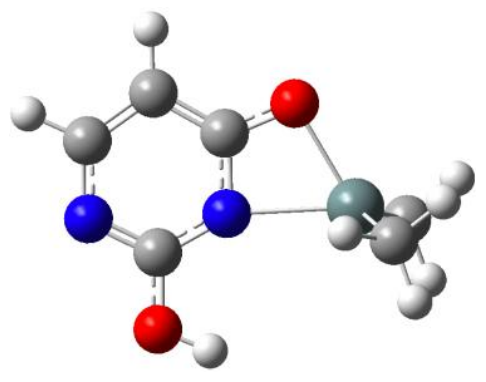

Ura-O4N3-O2H-1

75.5 (66.2)

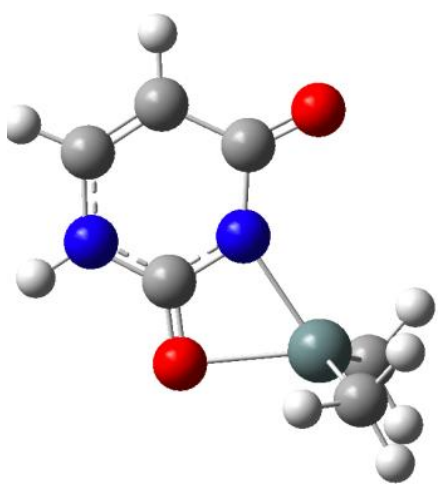

Ura-O2N3

$17.2(27.0)$

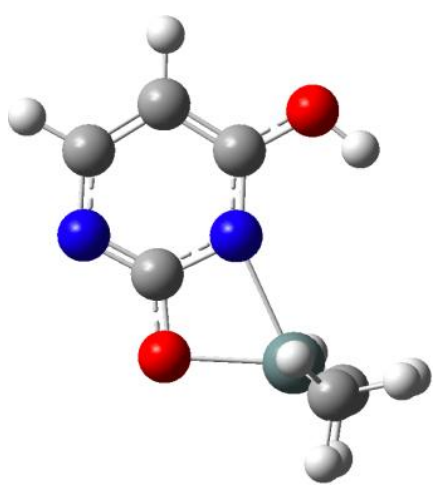

Ura-O2N3-O4H-1

$74.0(64.5)$

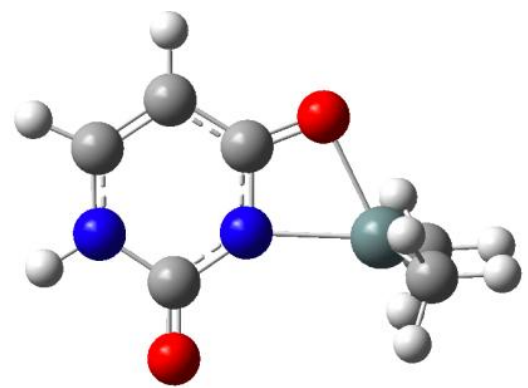

Ura-04N3

$0.0(0.0)$

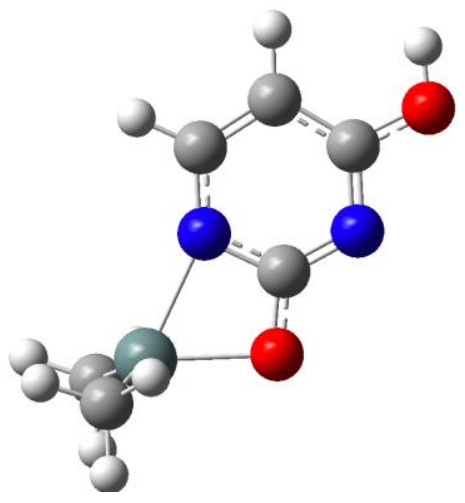

Ura-O2N1-O4H-1

56.2 (43.2)

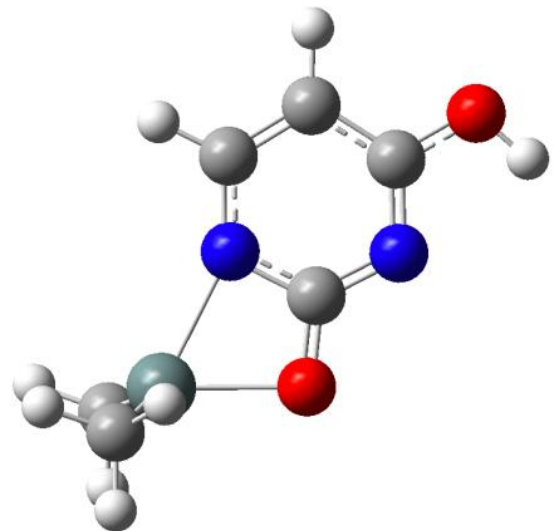

Ura-O2N1-O4H-2

32.5 (21.4)

Figure 2: Structure and $\operatorname{CCSD}(\mathrm{T}) / 6-31+\mathrm{G}(\mathrm{d}, \mathrm{p}) / / \mathrm{M} 11 \mathrm{~L} / 6-31+\mathrm{G}(\mathrm{d}, \mathrm{p}) .+\mathrm{ZPE}$ relative energies $(\mathrm{kJ} / \mathrm{mol})$ of the lowest-energy structures obtained for the $\left[\left(\mathrm{CH}_{3}\right)_{2} \mathrm{Sn}(\mathrm{Ura}-\mathrm{H})\right]^{+}$complex. Values obtained at the M11L/6-31+G(d,p)+ZPE level are given in parenthesis. 

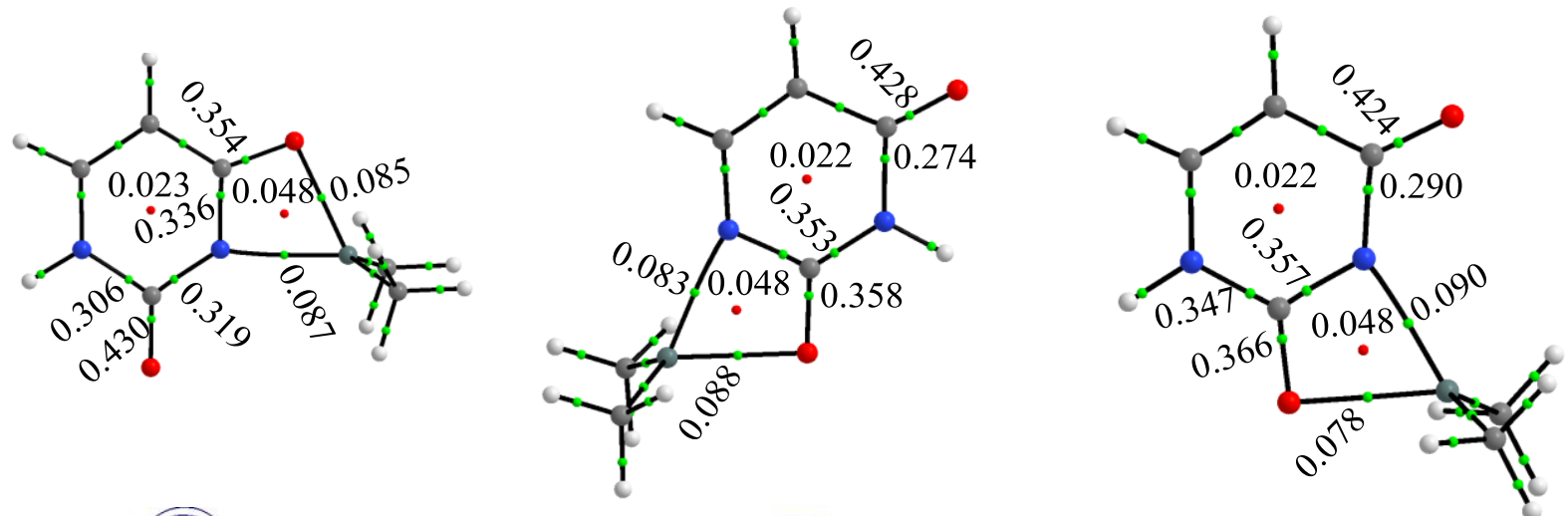

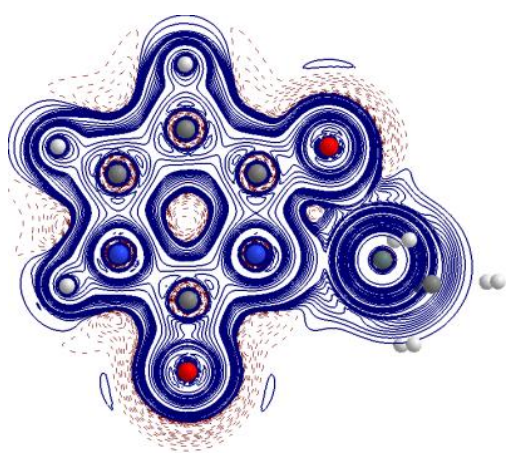

Ura-04N3

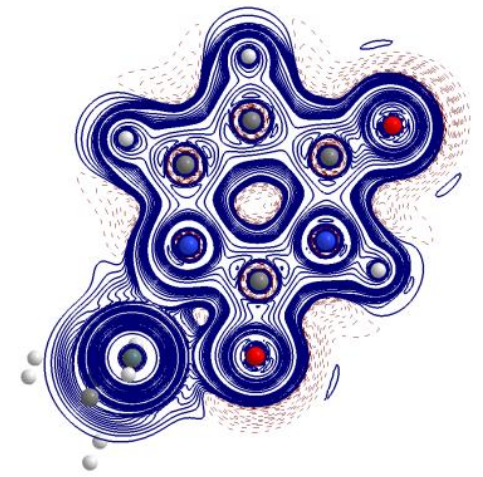

Ura-02N1

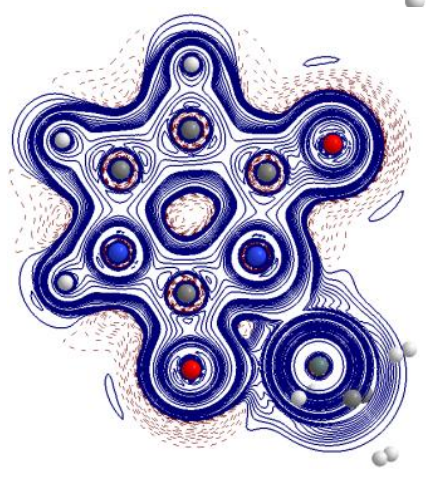

Ura-02N3

Figure 3: AIM topological analysis of the structures involving the diketo forms of uracil 

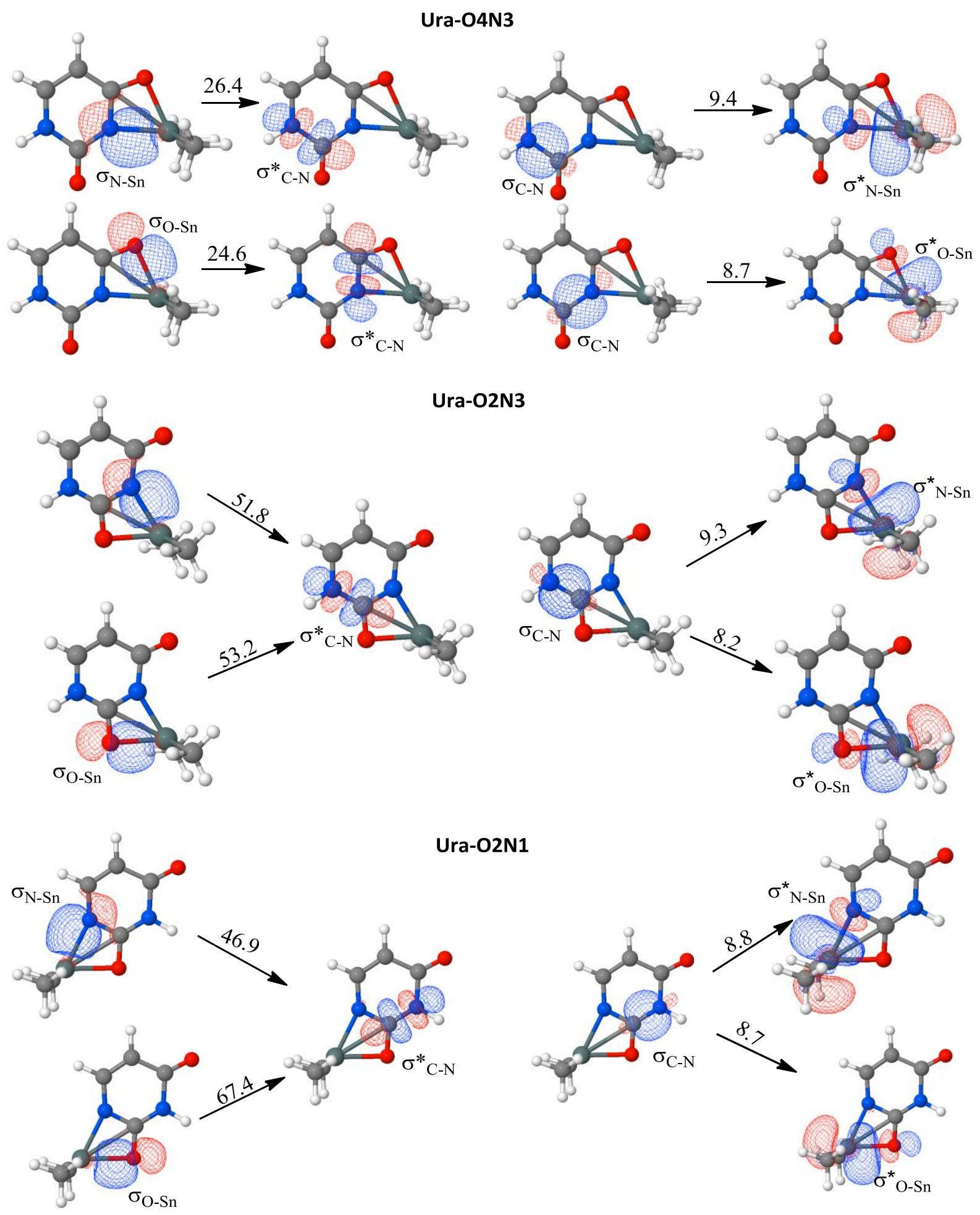

Figure 4: NBO molecular orbital interactions between occupied and empty orbitals in the most important complexes (values are $\mathrm{kJ} / \mathrm{mol}$ ). 


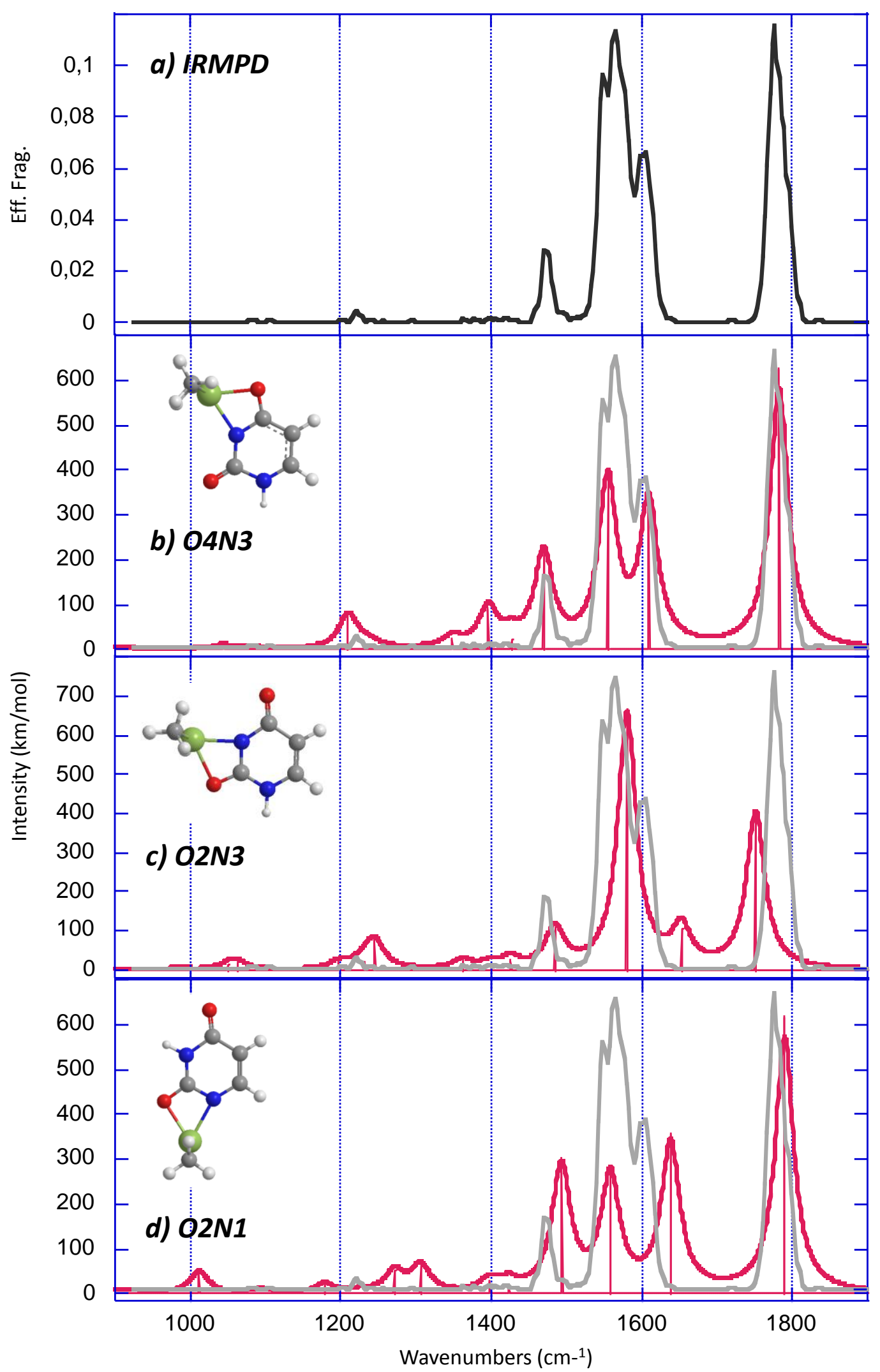

Figure 5: (a) IRMPD spectrum obtained for the $\left[\left(\mathrm{CH}_{3}\right)_{2} \mathrm{Sn}(\mathrm{Ura}-\mathrm{H})\right]^{+}$complex compared to DFT-computed IR absorption spectra (b-d) of some relevant structures. The experimental IRMPD spectrum is overlayed in grey 


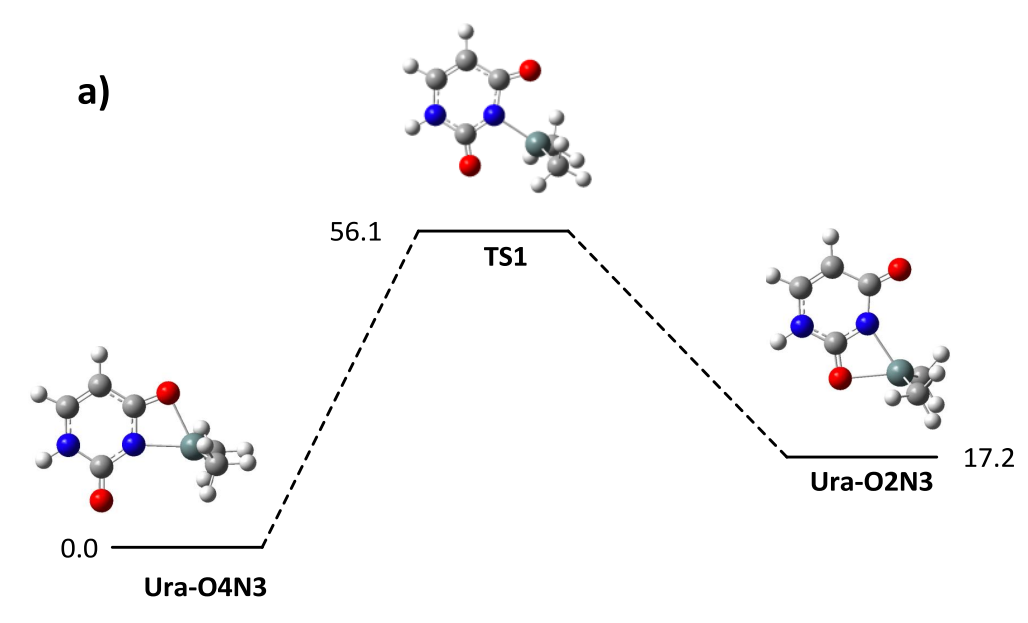

b)

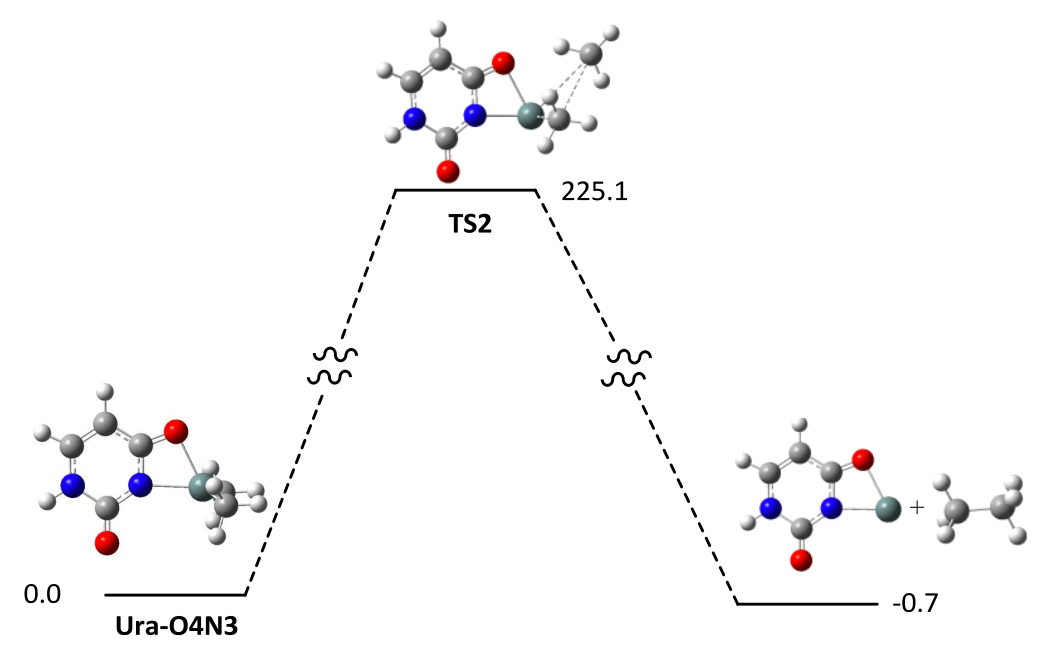

c)
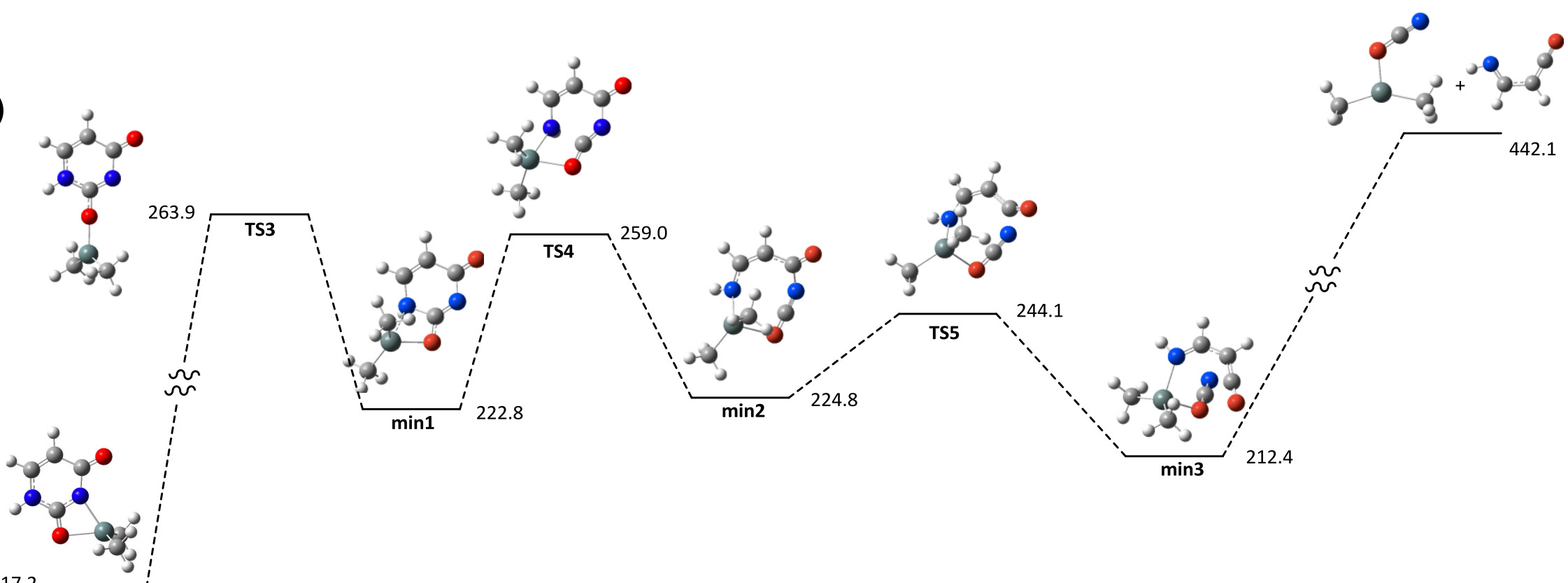

$17.2 \underset{\text { Ura-02N3 }}{1}$

Figure 6: Energy profile associated with the a) Ura-O4N3 $\rightarrow$ Ura-O2N3 interconversion, b) the formation of $\mathrm{C}_{2} \mathrm{H}_{6}$ and $[\mathrm{Sn}(\mathrm{Ura}-\mathrm{H})]^{+}$fragments $(\mathrm{m} / \mathrm{z} 231)$, and c) the formation of $\left(\mathrm{C}_{3}, \mathrm{H}_{3}, \mathrm{O}, \mathrm{N}\right)$ and $\left[\left(\mathrm{CH}_{3}\right)_{2} \mathrm{SnNCO}\right]^{+}$fragments $\left(\mathrm{m} / \mathrm{z}\right.$ 192) from the $\left[\left(\mathrm{CH}_{3}\right)_{2} \mathrm{Sn}(\mathrm{Ura}-\mathrm{H})\right]^{+}$precursor ion. Relative energies are given in $\mathrm{kJ} / \mathrm{mol}$ at the $\operatorname{CCSD}(\mathrm{T}) / 6-31+\mathrm{G}^{* *} / / \mathrm{M} 11 \mathrm{~L} / 6-31+\mathrm{G}^{* *}$ level of theory. 
Table 1: product ions observed in the fragmentation of different labeled uracil $\left[\left(\mathrm{CH}_{3}\right)_{2} \mathrm{Sn}(\mathrm{Ura}-\mathrm{H})\right]^{+}$complexes. $m / z$ values are given for the ions including the ${ }^{120} \mathrm{Sn}$ isotope.

\begin{tabular}{|c|c|c|c|c|c|c|c|c|}
\hline Uracil & Precursor ion & Product i & & & & & & \\
\hline & {$\left[\left(\mathrm{CH}_{3}\right)_{2} \mathrm{Sn}(\mathrm{Ura}-\mathrm{H})\right]^{+}$} & {$[\mathrm{Sn}(\mathrm{Ura}-\mathrm{H})]^{+}$} & {$\left[\left(\mathrm{CH}_{3}\right)_{2} \mathrm{Sn}\left(\mathrm{C}_{3}, \mathrm{H}_{2}, \mathrm{~N}, \mathrm{O}\right)\right]^{+}$} & {$\left[\left(\mathrm{CH}_{3}\right)_{2} \mathrm{Sn}(\mathrm{C}, \mathrm{N}, \mathrm{O})\right]^{+}$} & {$\left[\left(\mathrm{CH}_{3}\right)_{2} \mathrm{Sn}\left(\mathrm{C}_{2}, \mathrm{H}, \mathrm{O}\right)\right]^{+}$} & {$\left[\mathrm{Sn}\left(\mathrm{C}_{3}, \mathrm{H}_{2}, \mathrm{~N}, \mathrm{O}\right)\right]^{+}$} & {$\left[\left(\mathrm{CH}_{3}\right) \mathrm{Sn}(\mathrm{C}, \mathrm{N}, \mathrm{O})\right]^{+}$} & {$[\mathrm{Sn}(\mathrm{C}, \mathrm{N}, \mathrm{O})]^{+}$} \\
\hline & & $-\mathrm{C}_{2} \mathrm{H}_{6}$ & $-\mathrm{H}, \mathrm{N}, \mathrm{C}, \mathrm{O}$ & $-\mathrm{C}_{3} \mathrm{H}_{3} \mathrm{NO}$ & $-\mathrm{H}, \mathrm{N}, \mathrm{C}, \mathrm{O} /-\mathrm{HCN}$ & $\begin{array}{l}-\mathrm{C}_{2} \mathrm{H}_{6} \mathrm{l} \\
-\mathrm{H}, \mathrm{N}, \mathrm{C}, \mathrm{O}\end{array}$ & $-\mathrm{C}_{3} \mathrm{H}_{3} \mathrm{NO} /-\mathrm{CH}_{3}$ & $\begin{array}{l}-\mathrm{C}_{3} \mathrm{H}_{3} \mathrm{NO} / \\
-\mathrm{C}_{2} \mathrm{H}_{6}\end{array}$ \\
\hline not labelled & $m / z 261$ & $\mathrm{~m} / \mathrm{z} 231$ & $\mathrm{~m} / z 218$ & $m / z 192$ & $m / z 191$ & $m / z 188$ & $m / z 177$ & $\mathrm{~m} / \mathrm{z} 162$ \\
\hline $2-{ }^{13} \mathrm{C}$ & $\mathrm{m} / \mathrm{z} 262$ & $\mathrm{~m} / \mathrm{z} 232$ & $\mathrm{~m} / \mathrm{z} 218$ & $\mathrm{~m} / \mathrm{z}, 193$ & $\mathrm{~m} / \mathrm{z} 191$ & $\mathrm{~m} / \mathrm{z} 188$ & $\mathrm{~m} / \mathrm{z} 178$ & $\mathrm{~m} / \mathrm{z} 163$ \\
\hline $2-{ }^{13} \mathrm{C}-1,3-{ }^{15} \mathrm{~N}_{2}$ & $m / z 264$ & $m / z 234$ & $m / z 219$ & $\mathrm{~m} / \mathrm{z} 194$ & $m / z 191$ & $m / z 189$ & $m / z 179$ & $m / z 164$ \\
\hline
\end{tabular}

Table 2: Natural charge (in e) on the metal and DMT moiety in the complex, and Wiberg bond index of the most relevant bonds in the complexes

\begin{tabular}{|l|c|c|c|c|c|}
\hline \multirow{2}{*}{ Structure } & \multicolumn{3}{|c|}{ Charge (e) } & \multicolumn{2}{c|}{ Wiberg bond index } \\
\hline & $\mathrm{Q}_{\mathrm{Sn}}$ & $\mathrm{Q}_{\mathrm{Sn}(\mathrm{CH} 3) 2}$ & $\mathrm{Q}_{(\mathrm{Ura}-\mathrm{H})}$ & Sn-O & Sn-N \\
\hline Ura-O4N3 & 2.23 & 1.52 & -0.52 & 0.328 & 0.372 \\
\hline Ura-O2N3 & 2.23 & 1.53 & -0.53 & 0.295 & 0.383 \\
\hline Ura-O2N1 & 2.23 & 1.53 & -0.53 & 0.326 & 0.366 \\
\hline
\end{tabular}


Table 3: Experimental and computed IR vibrational bands for the $\left[\left(\mathrm{CH}_{3}\right)_{2} \mathrm{Sn}(\mathrm{Ura}-\mathrm{H})\right]^{+}$ complex

\section{Ura-04N3}

\begin{tabular}{|c|c|c|c|}
\hline \multicolumn{2}{|c|}{$\begin{array}{l}\text { Wavenumbers } \\
\left(\mathrm{cm}^{-1}\right)\end{array}$} & \multirow[t]{2}{*}{$\begin{array}{c}\text { DFT-computed } \\
\text { intensities }(\mathrm{km} / \mathrm{mol})\end{array}$} & \multirow[t]{2}{*}{ Vibrational mode } \\
\hline Exp. & Calc. $^{a}$ & & \\
\hline \multirow[t]{2}{*}{1220} & 1210 & 82 & $\delta \mathrm{CH}+\delta \mathrm{N} 1 \mathrm{H}$ \\
\hline & 1396 & 92 & $v \mathrm{~N} 3 \mathrm{C} 4$ \\
\hline 1475 & 1469 & 225 & $\delta \mathrm{N} 1 \mathrm{H}+v \mathrm{C} 4 \mathrm{O} 4$ \\
\hline 1565 & 1555 & 400 & $v \mathrm{C} 4 \mathrm{C} 5+v \mathrm{~N} 1 \mathrm{C} 6$ \\
\hline 1603 & 1609 & 345 & v C5C6 \\
\hline 1780 & 1782 & 625 & $\checkmark \mathrm{C} 2 \mathrm{O} 2$ \\
\hline
\end{tabular}

a) Scaled by a factor of 0.98

\section{Ura-O2N3}

\begin{tabular}{c|c|c|c}
\hline \multicolumn{2}{c|}{$\begin{array}{c}\text { Wavenumbers } \\
\left(\mathrm{cm}^{-1}\right)\end{array}$} & $\begin{array}{c}\text { DFT-computed } \\
\text { intensities }(\mathrm{km} / \mathrm{mol})\end{array}$ & \\
\hline Exp. & Calc. $^{\text {a }}$ & 76 & $v$ N3C4 \\
\hline 1220 & 1245 & 110 & $v$ C2N3 \\
\hline 1475 & 1484 & 704 & $v$ C2O2+ $\delta$ N1H \\
\hline 1565 & 1555 & 108 & $v$ C5C6 \\
\hline 1780 & 1652 & 433 & $v$ C4O4 \\
\hline
\end{tabular}

a) Scaled by a factor of 0.98

\section{Ura-O2N1}

\begin{tabular}{c|c|c|c}
\hline \multicolumn{2}{c|}{$\begin{array}{c}\text { Wavenumbers } \\
\left(\mathrm{cm}^{-1}\right)\end{array}$} & $\begin{array}{c}\text { DFT-computed } \\
\text { intensities }(\mathrm{km} / \mathrm{mol})\end{array}$ & \\
\hline 1220 & Calc. $^{\text {a }}$ & & Vibrational mode \\
\hline & 1271 & 51 & $\delta \mathrm{CH}$ \\
\cline { 2 - 4 } & 1306 & 65 & $\delta \mathrm{N} 3 \mathrm{H}$ \\
\hline 1475 & 1493 & 302 & $v \mathrm{C} 2 \mathrm{O} 2$ \\
\hline 1565 & 1558 & 277 & $v \mathrm{C} 5 \mathrm{C} 6+v \mathrm{C} 2 \mathrm{~N} 3$ \\
\hline & 1638 & 357 & $v \mathrm{C} 4 \mathrm{O} 4$ \\
\hline
\end{tabular}

a) Scaled by a factor of 0.98 
TOC graphic

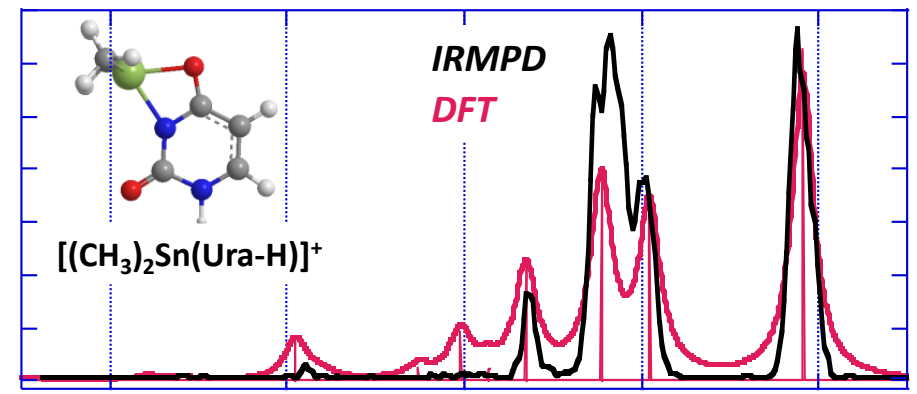

